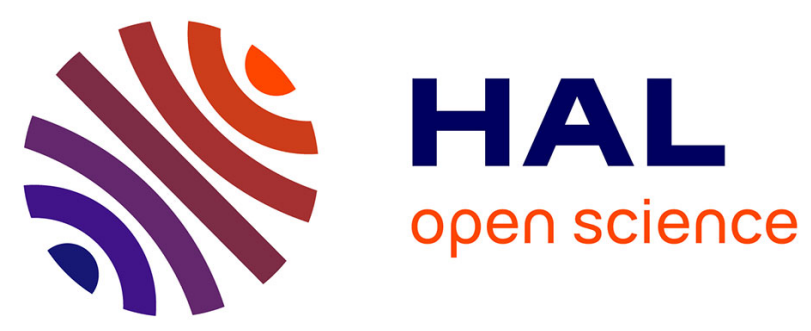

\title{
Towards a more resilient European Union after the COVID-19 crisis
}

Amélie Barbier-Gauchard, Meixing Dai, Claire Mainguy, Jamel Saadaoui, Moïse Sidiropoulos, Isabelle Terraz, Jamel Trabelsi

\section{- To cite this version:}

Amélie Barbier-Gauchard, Meixing Dai, Claire Mainguy, Jamel Saadaoui, Moïse Sidiropoulos, et al.. Towards a more resilient European Union after the COVID-19 crisis. Eurasian Economic Review, 2021, 11, pp.321-348. 10.1007/s40822-021-00167-4 . hal-03196689v2

\section{HAL Id: hal-03196689 \\ https://hal.science/hal-03196689v2}

Submitted on 7 Apr 2023

HAL is a multi-disciplinary open access archive for the deposit and dissemination of scientific research documents, whether they are published or not. The documents may come from teaching and research institutions in France or abroad, or from public or private research centers.
L'archive ouverte pluridisciplinaire HAL, est destinée au dépôt et à la diffusion de documents scientifiques de niveau recherche, publiés ou non, émanant des établissements d'enseignement et de recherche français ou étrangers, des laboratoires publics ou privés. 


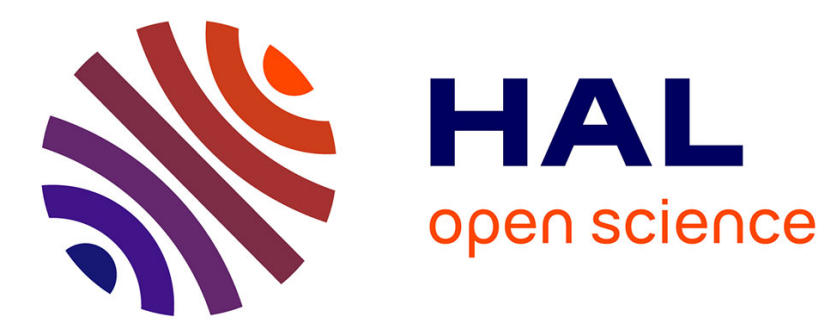

\section{Towards a more resilient European Union after the COVID-19 crisis}

Amélie Barbier-Gauchard, Meixing Dai, Claire Mainguy, Jamel Saadaoui, Moïse Sidiropoulos, Isabelle Terraz, Jamel Trabelsi

\section{To cite this version:}

Amélie Barbier-Gauchard, Meixing Dai, Claire Mainguy, Jamel Saadaoui, Moïse Sidiropoulos, et al.. Towards a more resilient European Union after the COVID-19 crisis. 2020. hal-03008144

\section{HAL Id: hal-03008144 \\ https://hal.science/hal-03008144}

Preprint submitted on 16 Nov 2020

HAL is a multi-disciplinary open access archive for the deposit and dissemination of scientific research documents, whether they are published or not. The documents may come from teaching and research institutions in France or abroad, or from public or private research centers.
L'archive ouverte pluridisciplinaire HAL, est destinée au dépôt et à la diffusion de documents scientifiques de niveau recherche, publiés ou non, émanant des établissements d'enseignement et de recherche français ou étrangers, des laboratoires publics ou privés. 


\title{
«Towards a more resilient European Union after the COVID-19 crisis»
}

\author{
$\underline{\text { Auteurs }}$ \\ Amélie Barbier-Gauchard, Meixing Dai, Claire Mainguy, Jamel Saadaoui, \\ Moïse Sidiropoulos, Isabelle Terraz and Jamel Trabelsi
}

Document de Travail $n^{\circ} 2020-33$

Bureau d'Économie

Théorique et Appliquée

BETA

www.beta-umr7522.fr

@beta_economics

Contact :

jaoulgrammare@beta-cnrs.unistra.fr

Juillet 2020 


\title{
Towards a more resilient European Union after the COVID-19 crisis
}

Amélie Barbier-Gauchard*, Meixing Dai*, Claire Mainguy*, Jamel Saadaoui**, Moïse

Sidiropoulos*, Isabelle Terraz ${ }^{*}$ and Jamel Trabelsi*

University of Strasbourg, University of Lorraine, BETA, CNRS, 67000, Strasbourg, France.

\begin{abstract}
The pandemic crisis constitutes an unprecedented challenge for the European Union and for the Euro Area. Indeed, European institutional architecture can be viewed as being half-way between an association of sovereign states (like the United Nations, for example) and a politically integrated federation (like the United States for example). In this original construction, competences on several matters (such as economic, political, social and health issues, etc.) are shared at the European level, but also at the national and local levels in more complex ways than in fully integrated federations. To improve the resilience of the European Union to violent external shocks, the main objective of this paper is to determine to what extent these competences have to be transferred to the federal level. In this respect, we will consider whether a federal leap is necessary in several areas namely (i) monetary and fiscal policy (rules), (ii) labor markets policy and social models, migratory flows and skill shortages, and cooperation policy and (iii) renewed industrial policy and exchange rates. Despite a highly uncertain context, we outline some perspectives for the future of the European Union.
\end{abstract}

Keywords: European Union, Pandemic Crisis, Economic Policy, Resilience.

JEL: F33, E52, E62, F22, J61, L52.

\footnotetext{
- The authors are grateful to Brian Wallis and Katharina Priedl for proofreading. All errors or omissions are ours.

* Corresponding authors

** Principal corresponding author

Email addresses: abarbier@unistra.fr (Amélie Barbier-Gauchard), dai@unistra.fr (Meixing Dai),

claire.mainguy@unistra.fr (Claire Mainguy), saadaoui@unistra.fr (Jamel Saadaoui), sidiro@unistra.fr (Moïse

Sidiropoulos), terraz@unistra.fr (Isabelle Terraz), trabelsi@ unistra.fr (Jamel Trabelsi)

URL: http://www.beta-umr7522.fr/-SAADAOUI-Jamel (Jamel Saadaoui)
} 


\section{Introduction}

The COVID-19 crisis has clearly shown that the European institutions were not able to face this violent exogenous shock. On the arrival of this novel coronavirus on European soil in France at the end of January 2020, we have expected a coordinated response at the European level in order to contain the expansion and the diffusion of the severe acute respiratory syndrome coronavirus 2 (SARS-CoV 2) within the European Union (EU, hereafter). Instead, each country has followed a national strategy as witnessed by the closure of borders as from mid-March when Poland, Austria and Slovenia decided to close their borders to Italians. These decisions have led to a de facto suspension of the Schengen Agreement. Even if these political decisions were motivated by the health context, this is not a minor outcome since we can reasonably consider that free circulation in the Schengen space is a fundamental pillar of the nascent European identity. Thus, the suspension of free circulation in Europe can be viewed as the symbol of the lack (maybe the absence) of efficient coordination between Member States in the fight against the SARS-CoV 2.

The European institutions were not able to provide a comprehensive framework to Member States in order to exploit the potential complementarities between Europeans countries. For example, countries like Germany with higher capacities in equipment used to perform cardiopulmonary resuscitation could have exported some of these medical devices to countries like Italy that desperately needed them when the diffusion of SARS-CoV 2 was extremely rampant in that country. In the same vein, countries with higher capacities in textile products like in Eastern Europe could have exported masks to the rest of the European Union. Indeed, there is some empirical evidence indicating that lockdowns alone are not sufficient to rein in the virus' diffusion at the beginning of an outbreak. Lockdown measures must be accompanied by several measures like hand hygiene and wearing masks and, above all, by testing, tracking and isolating the potential bearers of the virus (Zhou et al. 2020; Shim et al. 2020; Cheng et al. 2020). In this respect, as we can observe in the following figure 1, it is not surprising to observe that case fatality ratios (i.e. the ratio between the number of confirmed deaths and confirmed cases $)^{1}$ are so different in the EU, since each country has followed a national strategy and faced the virus' outbreak at different moments.

\footnotetext{
${ }^{1}$ An important indicator in epidemiology, the case fatality ratio is surrounded by uncertainties during an outbreak of the pandemic. However, a comparison with the world average and the EU average could help to reduce these uncertainties.
} 
Figure 1. Case fatality ratios in percent for some selected Member States of the EU

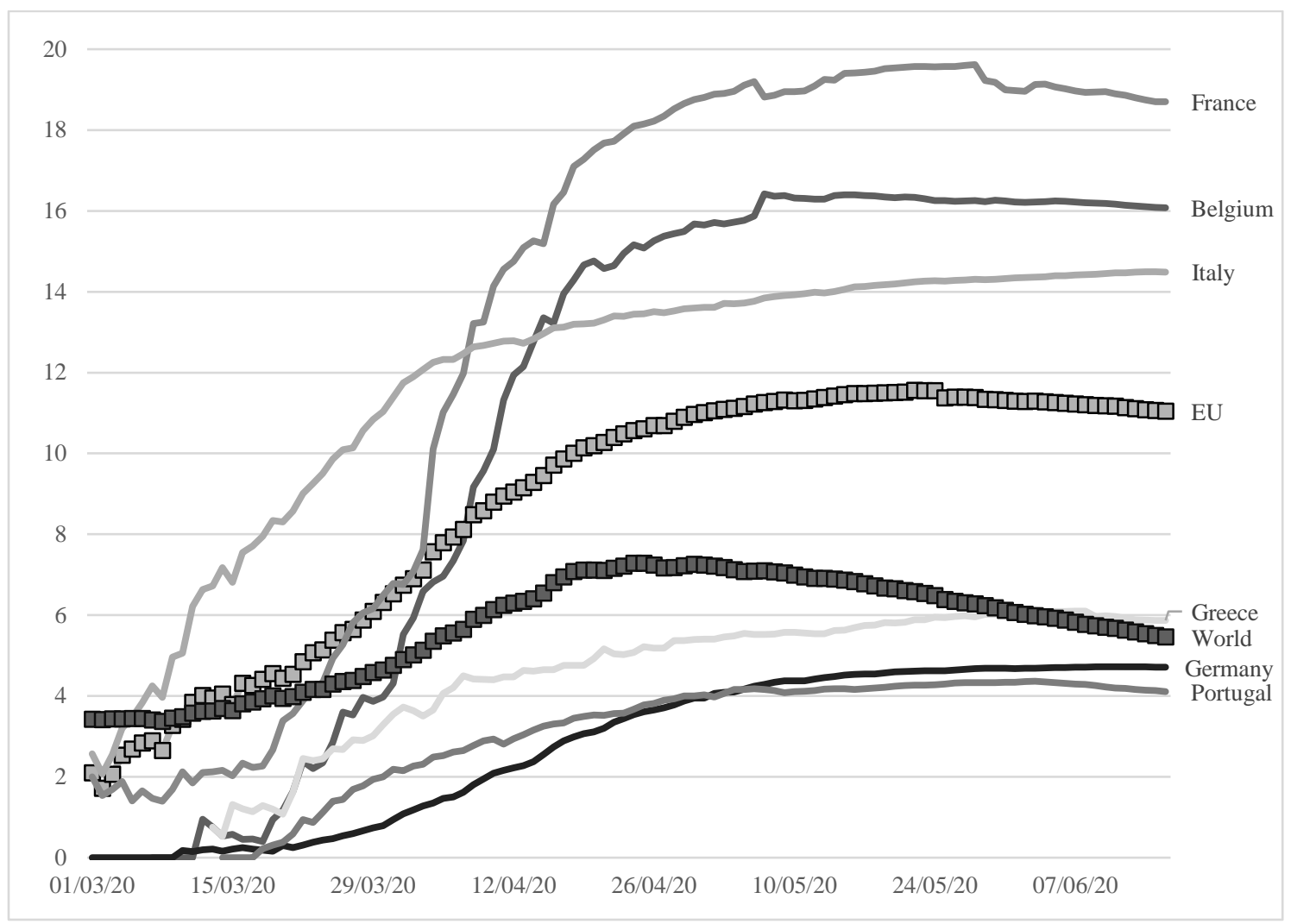

Source: European CDC, OurWorldInData.org/Coronavirus.

At the beginning of June 2020, several European countries have progressively begun to exit their lockdown measures and reopen theirs borders. Once again, these decisions have been taken considering the epidemic situation at the national level without coordination at the European level. For example, Italy reopened its border with France on 3 June 2020, 12 days before France reopened her border with Italy. The European commission has recommended opening the border and de facto exiting lockdown measures on 15 June 2020. This recommendation is based on a one-size-fits-all approach, very common in the European institutions. Indeed, as shown empirically by Markel et al. (2020) for the 1918-1919 influenza pandemic in the United States, U.S. cities that implemented non-pharmaceutical interventions sooner (social distancing, lockdown measures, etc.) suffering greater delay in reaching their mortality peak, had lower peak mortality rates, and lower mortality rates. Besides, these aforementioned correlations, there was significant association between an increased duration of non-pharmaceutical interventions and a reduced total mortality burden. 
Thus, the recommendation of the European Commission does not consider that some countries have been hit by this novel coronavirus after the rest of the EU. Indeed, Portugal, who had been hit after the rest of the EU, decided to reopen its borders at the beginning of July 2020. This simple example illustrates very well the fact that European institutions are not very welldesigned to face the arrival and the public health consequences of a world-wide pandemic. Thus, this pandemic crisis has revealed several fundamental weaknesses in the institutional architecture of the EU. Moreover, some observers have used a logistic growth model to describe the dynamics of this disease. In this model, the number of cases seems to increase exponentially, reach a unique maximum and then decrease. Preliminary empirical evidence (Spencer and Golínski 2020) indicates that this 'classic' logistic model is rejected by the data for several Member States like Italy or Spain. Consequently, the current epidemic is far from being over.

We think that the European institutions have an essential role to play in the design of new policies that aim at providing better health security for citizens in the EU. Indeed, as witnessed by the outbreaks of SARS-CoV between 2002 and 2004, MERS from 2012, swine flu (H1N1) between 2009 and 2011, and Ebola between 2013 and 2016, it is far from impossible for the European Union and the World to face a new pandemic in future years as convincingly argued by Horton (2020). More generally, the European institutions and the Member States need to design economic policies that increase the resilience of the EU to violent exogenous shocks.

In the remainder of this paper, we examine several areas of economic policies in the EU in order to investigate the weaknesses revealed by the COVID-19 crisis. We analyze these economic policies in decreasing order of integration. We begin with the most integrated economic policy in the EU, namely the monetary policy. Indeed, in the second section, we analyze how monetary policy could interact with fiscal policy and fiscal rules to increase its efficacy. Then, we explore the potential beneficial effects of a harmonization of labor market regulation and social model in the third section. In the same section, we evaluate the impact of the COVID-19 crisis on migratory flows and cooperation policies. In the fourth section, we draw up some perspectives on a less integrated policy in the EU, namely the industrial policy. We conclude in the last section. 


\section{Interactions between monetary policy, fiscal rules and common public debt}

The common monetary policy is an effective tool to deal with the COVID-19 pandemic that affects all euro area countries simultaneously. Because the severity of the crisis varies from one Member State to another, the effectiveness of monetary policy differs across the Member States. Fiscal policy should take an active role in offsetting the economic effects of the crisis but are greatly limited by fiscal rules that are designed to limit excessive public deficits and debts in order to maintain the integrity of the euro area in the long run. Moreover, the no-bailout clause, designed to discourage excessive national debt, increases the risk of defaults of over-indebted national governments. ${ }^{2}$ This risk can be reduced by making monetary policy more aggressive, reforming some fiscal rules, and creating common public debt.

\subsection{Monetary policy}

Pessimistic anticipations in the financial market could lead the economy of the Economic and Monetary Union (EMU, hereafter) of the EU in a downward spiral that would seriously increase the risk of the eurozone's breakup. The ECB has a great role to play in stabilizing the financial market. It has to be aggressive in its actions, taking account of the worst-case scenario.

The aggressiveness of monetary policy in the worst-case scenario is supported by a number of studies that examine how the central bank should conduct policy when the implications of the robust control technique, whose application in macroeconomics is pioneered by Hansen and Sargent (2007), are integrated into monetary policy decisions (e.g. Giannoni 2002; Giannoni and Woodford 2002; Onatski and Stock 2002; Giordani and Söderlind 2004; Leitemo and Söderström 2008; Dai and Spyromitros 2012; Gonzalez and Rodriguez 2013; Qin, Sidiropoulos and Spyromitros 2013). Moreover, if private agents form expectations through adaptive learning, monetary policy should be even more aggressive in order to deal with the worst-case scenario (André and Dai 2018). Given the degree of uncertainty in the current situation, adaptive learning seems to be a credible hypothesis for describing the behavior of economic agents with regard to their expectation-formation processes.

\footnotetext{
2 The no-bailout clause is one of the basic principles defined in the Maastricht Treaty. Article 125 of the Treaty on the Functioning of the EU has made it illegal for one Member State to be rescued by the others since its 2007 version (also known as the Lisbon Treaty).
} 
By conducting aggressive policy, the ECB is able to deal with the worst-case scenario by implementing policy measures that reduce more drastically the impacts of exceptionally large negative supply and demand shocks on the eurozone economy than in normal circumstances, avoiding thus the self-fulfilling bad equilibrium feared by financial operators.

The ECB has actually been very reactive since March 2020 and remains in a position to do whatever is necessary to calm anxieties in the financial market. The ECB targets on the one hand the private sector. The initial measures include making available up to $€ 3$ trillion in liquidity through the ECB's refinancing operations and lending to banks at the lowest interest rate the ECB has ever offered, $-0.75 \%$. On the other hand, the ECB targets the public sector by announcing the Pandemic Emergency Purchase Program (PEPP) of an amount equal to $€ 750$ billion that mainly aims at stabilizing the eurozone's sovereign debt markets to avoid spikes in the spreads that some member countries have to bear compared to German bonds following the pandemic. ${ }^{3}$ On 4 June 2020 , the ECB decided to increase the envelope for the PEPP to $€ 1,350$ billion. To affect the whole term structure and hence the broader financial conditions, the ECB has made eligible for purchase under the PEPP the eurozone's public sector securities with a residual maturity ranging from 70 days up to a maximum of 30 years and 364 days. Notice that these measures are accompanied by the easing in regulatory ratios made by European banking supervisors that freed up an estimated $€ 120$ billion of extra bank capital, which can support considerable lending capacity by the euro area's banks.

\subsubsection{Factors that may aggravate macroeconomic risks}

Several factors could aggravate the economic and financial risk following the COVID-19 pandemic and make the worst-case scenario even more difficult to deal with.

The drastic reduction in economic activity in many sectors may increase business failures and the number of households unable to repay their loans, causing banks to undergo substantial losses. It is therefore more likely that some banks will experience major difficulties in the coming months. The transmission of the economic effects of the Covid-19 pandemic to the banking sector could induce financial instability and make the current economic recession more severe. As a result, the ECB and national governments should pay particular attention to the stability of the banking sector.

\footnotetext{
${ }^{3}$ With the PEPP, the ECB bought a range of assets including not only government bonds, but also securities issued by European supranational institutions, corporate bonds, asset-backed securities and covered bonds.
} 
This risk is all the more important as the expansion cycle was already showing signs of weakness before the pandemic. The pandemic emerges in a context where growth is being supported by extremely accommodative monetary and fiscal policies, which have raised the rate of GDP growth above its long-term potential in a number of industrialized countries. In fact, the quantitative easing policies implemented during and after the global financial crisis of 2008-09 have barely been lifted. Key interest rates are at their lowest level in the euro area. In the United States, they have been raised only slightly and cautiously. The room for maneuver of monetary policy is not being restored by significant interest rate hikes as in previous cycles. The very accommodative fiscal policy has led to high budget deficits and rising public debts in many industrialized countries over the past decade. Many governments are giving up creating fiscal space for a counter-cyclical fiscal policy that is able to stimulate or support the economy in the event of a major economic and financial crisis. In the euro area, a few countries, including Germany and the Netherlands, have been the exception with budget surpluses in recent years according to Eurostat.

The economic growth after the global financial crisis of 2008-09 also depended on excessive positive wealth and balance-sheet effects: the exceptional rise in stock prices since March 2009, driven by extremely accommodating monetary and fiscal policies, is pushing households to spend more. The return of the pendulum swing may bring very unpleasant surprises to economies that lack growth engines. The recent stock market plummeting following the worsening global health situation is likely to significantly reduce household demand for goods and services and thus the GDP growth. Lower asset prices may also have a negative impact on firms and banks that hold a large amount of financial assets on their balance sheets, thereby tightening the financing constraints of these entities.

Starting at the peak of an expansionary cycle excessively based on public and private debt, it is highly likely that some systemically important public and private borrowers will face major difficulties as a result of the current severe economic downturn. A financial crisis could be triggered as a result of this downturn and would in turn aggravate the economic recession.

The strong global interdependence in the production process is also a major factor aggravating macroeconomic risks in the eurozone countries that are largely open to foreign trade. The COVID-19 pandemic leads more easily than any other pandemic known until now to major disruptions in the production and supply chains that link firms around the world. Barriers put in 
place to limit the transmission of the coronavirus reduce the interconnectedness between countries, thus preventing the smooth functioning of the global economy and deepening the recession. Until effective treatments and vaccines against COVID-19 are found, the fight against this pandemic will not stop. Some lighter lockdown measures will still be needed if there are countries or regions where the pandemic persists. Measures restricting the transport of goods and the mobility of people may have a lasting impact on the global economy, particularly on certain sectors that strongly depend on transport services and could be the vector for the spread of the coronavirus.

Moreover, the current health crisis is aggravating the budgetary difficulties of a number of States and could cause the failure of some of them. Such defaults will affect the financial and nonfinancial sectors of the country concerned, and possibly the international financial markets if there is strong foreign participation in the financing of the defaulting State and the national financial sector in crisis. Such crises, by their contagion effect, can make the atmosphere in the international financial markets deleterious, thus provoking a flight of investors to assets of quality and seriously deteriorate the financial situation of other States whose level of indebtedness is already high as a result of the massive budget deficits caused by the COVID-19 pandemic. In the euro area, Italy, Spain and Portugal, among others, are most exposed to this type of risk that could lead to twin selffulfilling sovereign debt and banking crises.

\subsubsection{Limits to the effectiveness of monetary policy}

Central banks primarily aim to stabilize inflation and output. Since the global financial crisis of 2008-09, some central banks have implicitly or explicitly assumed responsibility for financial stability. This translates for them into a significant role in macro-prudential supervision, an active communication with financial operators, and even the implementation of support measures in the event of a sharp fall in asset prices.

Prior to the current health crisis, interest rates set by central banks in developed countries were close to historically low levels. Such an interest rate policy is an important support for financial and real asset prices, hence generating positive wealth and balance-sheet effects on which a significant part of economic growth relies. The fact that central banks have not created sufficient room for maneuver means that they cannot provide massive support in a major crisis where the effects of the COVID-19 pandemic are added to an increased risk of cyclical recession after more 
than a decade of economic expansion. The few small interest rate cuts by central banks across the world since the health crisis will have little impact on the world economy. In the euro area, some banks, not being able to lend enough for a variety of reasons, have even been suffering from negative rates on excess reserves for some time.

Low interest rates have shown their limits as a stimulus to economic growth. This type of policy redistributes wealth between borrowers and savers. The effectiveness of the policy relies on increased spending by borrowers and can be reduced by a change in the behavior of savers. The latter, instead of reducing their savings in the face of falling interest rates, could increase their savings effort to reach an initially set savings target, thus partially cancelling out the stimulating effect of the low interest rate policy. In addition, the COVID-19 pandemic could encourage households to save more and firms to reduce their debt in the future. These include in particular those who have been experiencing financial difficulties during this COVID-19 crisis.

Despite the limited room for maneuver in interest rate policy, central banks can still play an important role by implementing unconventional monetary policy measures, including the massive purchase of public and private bonds of different maturities and varying degrees of risk. In a context where massive budget deficits need to find sources of funding, such unconventional measures help, inter alia, to reduce tensions in public and private debt markets. This avoids a sharp generalized rise in interest rates and makes it easier for governments and private firms to finance, thereby reducing the risk of banking and sovereign debt crises. This type of risk is particularly high in the euro area given its institutional constraints.

Monetary policy should not be considered as the miraculous measure able to fully erase the serious negative economic impacts of this health crisis, despite its effectiveness in mitigating the negative effects of the pandemic on the economy and in ensuring financial stability by preventing the vicious circles of economic and financial crises from occurring. In particular, monetary policy could not compensate for the decline in income, which is real and very large. An increase in the quantity of money via bank loans only produces wealth in certain situations: those characterized by significant financing and liquidity constraints, which prevent the optimal intertemporal tradeoff by households between present and future consumption and limit firms' production and investment; or those, which are rather rare, where self-fulfilling bad expectations have led the economy towards a bad equilibrium with abnormally low economic activity. In these situations, an increase in credits to the economy can generate additional growth without inflation. 
To deal with the current financial difficulties of many firms, simply injecting liquidity into the financial system is not enough to stem the fall in asset prices and to offset the effects of the health crisis on economic activities. Monetary policy actions should be taken to minimize the risk that this temporary health shock makes a long-lasting major adverse impact on the economy over the medium term by causing massive business failures and significant damage to the balance sheets of firms that survive. It is imperative to take specific measures aimed at firms that were in a good financial situation before the health crisis to preserve the production and distribution chains of goods and services so that these firms can resume normal operations once they come out of lockdown. This would lead to a good recovery of the labor market that preserves the employees' purchasing power effectively in the post-health crisis period. More specifically, central banks should provide incentives to induce banks to grant additional loans to firms in need and/or defer the repayment of existing loans. While such measures are effective, they cannot completely offset the effects of the COVID-19 pandemic on business failures. Indeed, this pandemic, through its significant and complex effects on the economy, increases information asymmetries between banks and borrowers, which push banks to become more prudent in their lending activities. Indeed, given regulatory constraints and risk management principles, banks cannot take the risk of extending credit to businesses that have a high probability of failing in the coming months.

\subsubsection{Institutional and economic constraints for the conduct of monetary policy in the EMU}

According to the Statute of the ECB, its primary objective is price stability in the euro area. It can only support growth if average inflation in the euro area is kept under control. Financial stability is now also a concern for the ECB when the risk of a systemic crisis threatens inflation stability and growth. To fulfill its financial stability tasks, the ECB monitors developments in the banking sectors of the euro area and the EU as a whole, as well as in other financial sectors, with a view to identifying possible vulnerabilities and to checking the resilience of the financial system.

The ECB conducts policy under specific economic and institutional constraints. The construction of the EMU has reduced the resilience of Member States to adverse macroeconomic and financial shocks due to the abandonment of national monetary sovereignty. The absence of banking and fiscal unions means that Member States are solely responsible for macroeconomic and financial shocks affecting their national economies. Insufficient mobility of production factors and 
lack of flexibility in national labor markets mean that the adjustment of an economy suffering from major adverse and asymmetric shocks cannot be implemented without great difficulty. The Stability and Growth Pact (SGP) is designed to limit budget deficits in order to avoid the moral hazard of Member States in their management of fiscal policies that, without any control, may oblige the ECB to monetize some Member States' public debt one day. There is an increased risk of bankruptcy for a highly indebted Member State because of the no-bailout clause in the Maastricht Treaty. Meanwhile, the role of national fiscal policy is strengthened by the abandonment of monetary sovereignty. This could imply very undesirable consequences for the national budget in the event of a banking crisis because each Member State was responsible for national banking regulation and supervision and the resolution of national banking crises. The national government has to bear fully the direct cost of a national banking crisis due to recapitalization of banks or other support measures and the indirect cost due to low tax revenues during a prolonged period after a banking crisis.

The ECB is responsible for conducting the common monetary policy for all euro area countries independently of any European authority and national governments. Given the heterogeneity of the Member States' economies, the common monetary policy could be too expansionary for some countries and too restrictive for others. The ECB could find it difficult to respond to the COVID-19 pandemic, which is a symmetrical shock but with heterogeneous consequences, if the constraint on the allocation keys for purchases of bonds issued by the Member States is not lifted. ${ }^{4}$ Moreover, the common monetary policy cannot be properly coordinated with the fiscal policies that are conducted by national governments in a sovereign manner but limited by the SGP. It is further constrained by the no-bailout clause, which stipulates that one Member State should not financially rescue another, while the ECB refrains from monetizing Member States' debts by buying them on the primary market.

There is an incompatibility, evidenced by the eurozone crisis of 2010-12, between the independence of the ECB, the fiscal sovereignty and the no-bailout clause (a discussion on this trilemma can be found in Beck and Prinz 2012). The no-bailout clause removes moral hazards, which could arise when the EMU's promise of a bailout induces a Member State to increase its sovereign debt. Such behavior would sooner or later destroy the foundations of the EMU.

\footnotetext{
${ }^{4}$ Until the COVID-19 crisis, the ECB bought public debt issued by the Member States according to their share in the ECB's capital. The current crisis has led the ECB to temporarily abandon this rule to ensure a better transmission of monetary policy.
} 
Therefore, in theory, imposing such a clause allows sovereignty over fiscal policy to be left to Member States. However, fiscal policy tends to hold monetary policy hostage if the Member States' budget deficits and public debt are not limited. Indeed, the SGP with its various forms is revealed to be ineffective in limiting public deficits and debts. There is a conflict between high and disparate levels of public debt in the Member States and a single monetary policy with a relatively low inflation target that limits the possibility of reducing the real value of public debt. Moreover, as fiscal authorities are responsible for rescuing national banks under their supervision, there is a "diabolical loop", according to the terminology of Brunnermeier et al. (2016), between the financial difficulties of a Member State and the banking crisis at the national level.

As the sovereign debt crisis of 2010-12 in the EMU has shown, the ECB could not refuse to play the role of last-resort lender to rescue over-indebted Member States at the risk of breaking up the EMU. This leads to a loss of independence of the ECB. Although both the SGP and the nobailout clause aim at making the euro area stable, failure to comply with the former increases the risk of the euro area splitting up. Indeed, the risks on sovereign debt are different across the euro area and should result in different interest rates despite the single monetary policy. This reduces the effectiveness of the monetary transmission mechanism in countries whose governments are subject to a risk of insolvency. Brandishing threats of exiting the euro area, these countries can put great pressures on the EMU to waive the no-bailout clause and abandon the independence of the ECB. Without this independence, however, the ECB risks losing credibility and thus the effectiveness of its policies in the future.

The contradictions raised above could be mitigated by reducing the ambitions of each of the three objectives. In terms of monetary policy, the ECB is implementing "quantitative easing" by buying large amounts of sovereign bonds to protect the euro area from the risks of deflation and break-up. On the financial side, the European Stability Mechanism (ESM), set up during the eurozone crisis, provides financial assistance to over-indebted Member States based on strict debt conditionality and debt sustainability. Moreover, by introducing the Euro Plus Pact, the EMU obliges Member States to improve their competitiveness and public finances through reforms. Finally, the creation of the banking union makes it possible to break the "diabolic loop" between the sovereign debt crisis and the banking crisis at the level of a Member State. Notice that the completion of a European banking union is hampered by obstacles to the creation of single deposit guarantee and it is not clear how the costs of resolution will be shared if a large amount of losses 
remains unabsorbed once the bail-in principle is applied. Despite these reforms, if the Member States do not give up their fiscal sovereignty, there is still a risk of crisis for the EMU in the long term, implying that either Member States in difficulty leave the euro area or strict rules for sovereign defaults are enacted.

The various reforms made since 2008 have enabled the euro area to be more resilient in the event of a crisis. However, institutional constraints in the EMU still limit the scale of short-term responses to the pandemic. To cope with the pandemic, the ECB has temporarily put aside the allocation keys for purchases of national bonds. Its audacity should be accompanied by fiscal policy measures that ease financial constraints without imposing fiscal austerity on national economies hit hard by the crisis. Seen from this point of view, the ESM is not an appropriate tool because the conditionalities it imposes discourage even those Member States with urgent funding need from applying for funding. To avoid a deadlock, the European Commission proposed, on 27 May 2020, to issue a common European debt of 750 billion euros, of which 500 billion are used to subsidize the countries most affected by the crisis.

\subsubsection{Risk sharing, helicopter drop of money and monetization of public debt}

Given the urgency of the economic situation, it is tempting for policy makers and economists to push the ECB to do a "helicopter drop of money", or in an equivalent way, to distribute an amount of money to each household, and/or to finance additional public spending through money creation in response to the COVID-19 pandemic (Galí 2020).

These policy measures are feasible to some extent. Nevertheless, their effectiveness in stimulating growth is limited (Dai 2011). Even if they become effective, there is a great risk that they may be misused for political reasons. Economists agree that a credible central bank has some power to create seigniorage revenue without causing inflation to shoot up. It makes little difference in the current crisis whether this seigniorage revenue is given to households and firms or used to finance the government's budget deficits. It should be borne in mind that the seigniorage revenue that can be raised is not so high in many countries and that an excessive recourse to money creation beyond the upper limit of this power is a source of high inflation and makes inflation difficult to control in the future. ${ }^{5}$ Moreover, the central bank may lose this power if it repeatedly abuses it,

\footnotetext{
${ }^{5}$ For example, in 2016 , the Fed paid out $\$ 92$ billion of its net profits to the U.S. federal government. The ECB's net profits vary between $€ 10$ and 30 billion over the period 2002-2015 (Gros 2016). This difference in the level of
} 
because economic agents may abandon the national currency in favor of foreign currencies and other assets.

The ECB is not mandated to play a role in redistributing the wealth. The helicopter money drop or the monetization of public debt could involve such redistribution since not all countries need and get the same help from the ECB. The ECB can create money from scratch, but the inflationary effects of such creation could adversely affect the wealth of people in Member States that receive less than proportionately the newly created money compared to their weight in the euro area's economy. Such a policy, that favors certain Member States more than others, could raise existential problems for the euro area. On the one hand, European identity is far from being fully achieved, hence limiting the solidarity between peoples of different Member States and the possibility of a systematic transfer from some countries to the others. On the other hand, some States are more likely to engage in large deficits due to their political and institutional structures while others are not. As a result, sharing the risk in the euro area should be simply called "transferring revenues" from some countries to the others. The basic principle of risk-sharing does not apply because for losses to be shared through insurance contracts, they should be known only with probability but not with certainty. The ECB could not do the job of transferring revenues if some countries refuse to pay for others. Net contributor countries anticipate that they would lose their money for ever and not get a fair financial return that would be expected if the basic principle of risk sharing was respected, while beneficiary countries always ask for money without any intention of giving it back, considering that the former have most profited from the EMU.

The helicopter drop of money is actually done in the EMU by national governments that give large scale financial aids and guarantees to firms facing great difficulties and compensate for the lost revenues of workers who are under lockdown or in temporary partial unemployment schemes.

The extraordinary public spending by national governments in the euro area raises fears that the ECB could resort to a large-scale monetization. This point of view is not shared by Blanchard and Pisani-Ferry (2020) who consider that the ECB is doing quite a good job and the fears of monetization are not well founded. Making available up to $€ 3$ trillion in liquidity through refinancing operations, including at negative interest rates, and implementing the large-scale

seigniorage revenue between the United States and the euro area is largely explained by the fact that US currency plays a central role in the world monetary system. 
Pandemic Emergency Purchase Program that amounts to $€ 1350$ billion, the ECB does not need to do a direct helicopter drop of money or/and a monetization of national governments' debt. The ECB's current stimulus measures are equivalent to a helicopter drop of money and a monetization of national governments' budget deficits as long as the ECB does exit from these measures. Such measures have the advantage of being reversible and hence are not inflationary when the conjuncture is well improved.

\subsection{Sense and nonsense of fiscal rules in the eurozone}

At the national level, fiscal policy is still the main economic policy tool that the Member States use to deal with the short-run negative effects of the COVID-19 pandemic. However, national governments are constrained by a number of fiscal rules that could reduce the effectiveness of fiscal policies. Some reforms are needed to remedy the weakness of actual fiscal policy rules revealed by the current crisis. A "smart" fiscal rule is needed to deal with the COVID-19 pandemic.

\subsubsection{Fiscal rules in the Euro Area in a nutshell}

The origins of fiscal discipline in the euro area date back to the Maastricht Treaty (1996). One of the main aims of the Maastricht Treaty is to launch the EMU project. This Treaty sets out the steps to take and the conditions to be met for a country to be eligible for the single currency. Among these conditions, called "convergence criteria", two criteria relate to public finance stability of the candidate countries for the EMU. Indeed, unsustainable national public finance would risk jeopardizing the stability of the newly created monetary union. It is therefore necessary to monitor the national public finance trend and ensure its sound management over the long term. Two indicators have been retained: national public debt of the candidate country must not exceed $60 \%$ of GDP (threshold set at $60 \%$ which corresponds to the average public debt-to-GDP ratio in the EU-15 at the end of the 90s), national public deficit must not exceed 3\% of GDP (threshold set at $3 \%$ with reference to the debt dynamic equation which gives the level of public deficit allowing public debt to be stabilized around $60 \%$ for a real activity growth rate at $3 \%$ and an inflation rate at $2 \%)$.

If the candidate country meets all these convergence criteria, it is then allowed to join the eurozone. Any country belonging to the EMU is then subject to a fiscal rule introduced by the 
Stability and Growth Pact (1996) and entered into force on January 1, 1999, with the birth of the eurozone. This fiscal rule could be qualified as the supranational fiscal rule, in contrast to the national fiscal rules also in force in most of the member countries of the eurozone. The Pact has two complementary objectives: the "stability" of public finance on the one hand, requiring eurozone countries to pursue sound management of public finance, and the "economic growth" in the EMU on the other hand, ensuring that national governments have enough leeway to intervene if necessary (more especially if a cyclical shock occurs).

To achieve these two complementary objectives, the Pact has two types of instruments: the "dissuasive" arm (public deficit ceiling to be respected, with sanctions imposed in case of nonrespect, and exceptions to the rule in very specific economic circumstances) and the "preventive" arm (multilateral surveillance procedure with "stability programs", multi-annual programs setting fiscal guidelines over 3 years and making it possible to have visibility on public finance for the next 3 years to come to achieve budget balance in the medium term).

Despite this fiscal rule, the eurozone has experienced several periods of turbulence (first crisis in 2004, Great Recession from 2007 to 2009, COVID-19 crisis since the end of 2019) which have constituted as many crises for fiscal discipline in the eurozone. Each time, the fiscal rule was reformed, considering that it was the rule which was imperfect... These successive reforms have led to a stack of indicators to be respected without in-depth reflection on the real reasons for the failures of fiscal discipline in the euro area. Following the reforms of 2005, 2011 and 2013, the fiscal rule in force in the eurozone has turned into a catalog of indicators to monitor, neither allowing to ensure real coercive disciplinary power over the Member States, nor providing a real monitor of the efficient management of national public finance.

\subsubsection{Lessons from past crises revealing fiscal discipline weaknesses}

To better understand the strengths and weaknesses of fiscal discipline in the euro area, it is interesting to refer to the seminal paper of Kopits and Symansky (1998) on the characteristics of an ideal fiscal rule. They identify eight properties that must be checked by the fiscal rule to be a "good" fiscal rule:

1. Suitability for the intended objective: the rule must make it possible to control the discretionary orientation of fiscal policy;

2. Clear definition: the indicator, the sanctions and the exceptions to the rule must be clearly explained; 
3. General consistency: the rule must be consistent with the objectives of economic policy;

4. Robust analytical foundations: the target and the reference value chosen must meet a precise economic justification;

5. Transparency: the rule must be understandable by public opinion;

6. Simplicity: the calculation of the target must be able to be done without requiring sophisticated calculation techniques;

7. Flexibility: governments must be able to continue to carry out their missions;

8. Credibility: control procedures and the application of sanctions must be applied in an impartial and consistent manner.

Even if Kopits and Symansky (1998) do not explicitly use the term of "fiscal rule effectiveness", their contribution nevertheless constitutes the cornerstone in the "good" fiscal rule debate. Moreover, Barbier-Gauchard et al. (2021) are interested in the link between fiscal rule and government efficiency to fuel useful debate on fiscal rules performance.

In the light of this analytical grid, the current fiscal rule in the EMU suffers from three major weaknesses. First, the current rule now considers too many (and sometimes redundant) indicators simultaneously (total public balance, structural balance, public debt, growth of public expenditure, multi annual public finance program) to be able to make a clear and unequivocal diagnosis on the current state of public finance management in the country.

Secondly, the current indicators of fiscal rule do not consider the fiscal functions identified by Musgrave (1959). More specifically, national public finance must be used for the allocation (production and supply of public goods and services), the redistribution of income (with a view to social justice) and the economic stabilization of activity when an economic shock occurs. In this context, in addition to measures which could be taken at the Community level for the EU as a whole, the fiscal rule must also allow countries to provide quality public services and ensure economic stabilization. The current rule has already planned to leave sufficient room for maneuver to countries in the event of a cyclical shock. Nevertheless, in order to meet the Maastricht convergence criteria, some countries had to put in place drastic reduction measures for some public spending, sometimes to the detriment of the quality of public services (education, health, security, etc.) and long-term growth public expenditure. For instance, the COVID-19 crisis highlights how heterogeneous and sometimes very stricken national health systems are. 
Finally, the current rule suffers from a cruel lack of credibility of the sanction for several reasons. Imposing a financial penalty on a country already in financial difficulty is nonsense. In addition, the procedure for imposing the sanction is too complex and not automatic, so that all countries well know that they will never be sanctioned. Moreover, the most efficient fiscal rule is the one the country has imposed on itself. This is the reason why, in the eurozone, national fiscal rules seem more effective than the supranational fiscal rule as underlined by Barbier-Gauchard et al. (2019). In other words, the current fiscal rule does not meet at least 3 of the 8 criteria of Kopits and Symansky (1998) analysis:

- Clear definition: the indicator, the sanctions and the exceptions to the rule must be clearly explained;

- General consistency: the rule must be consistent with the objectives of economic policy;

- Credibility: control procedures and the application of sanctions must be applied in an impartial and consistent manner.

\subsubsection{For a "smart" fiscal rule in the eurozone}

The COVID-19 context represents both an opportunity and a threat to the economic governance of the eurozone: an opportunity if public decision-makers seize this chance to commit themselves to adopting a smart supranational fiscal rule consistent with economic reality, and a threat if no lessons are learned from this new painful experience for monitoring national public finance.

Overall, the future "smart" fiscal rule for the eurozone must be designed considering the requirements which the Member States must face (supply of public goods and services, equity, economic stabilization, support for long-term growth) but also opportunities that European integration makes possible (such as the joint financing of major long-term investment programs, the pooling of some public expenditure at the community level, etc.).

Of course, all this is only feasible when heavily indebted countries have reduced the level of their public debt. Several non-mutually exclusive options for action are possible to remedy the weaknesses of the current fiscal rule in the EMU:

- to monitor only the structural public balance excluding public investment to free up financial leeway at the national level to ensure economic stabilization and support for long-term growth; 
- to centralize part of the national public expenditure for certain public goods and services in order to free up financial leeway at national level for the supply of public goods and services which must remain provided at the national level;

— to consider the "quality" of fundamental public goods and services vital to the wellbeing of citizens (education, health, security) in the assessment of the sound management (or not) of national public finance;

- to support national public investment programs with European co-funding obtained thanks to the power of the strike force of an organization for financing investment projects such as the European Investment Bank (EIB, hereafter);

- to replace the financial fine to be paid in the event of non-compliance with the rule by a sanction designed to cut all or part of the Community funding for the country which does not comply with the fiscal rule and an automatic sanctioning mechanism (no political decision to be taken).

In a nutshell, the future "smart" fiscal rule for the eurozone could be a rule only related to the structural balance excluding public investment (with a cut of all or part of the Community funding) accompanied by an ambitious program at the Community level to support public investment and monitor the quality of fundamental public goods and services for citizens. In addition, at the euro area level, a euro-zone budget considered as a European automatic fiscal stabilization mechanism could be a valuable complement to automatic fiscal stabilizers at the national level to cushion the effects of cyclical shocks on economic activity.

Nevertheless, much remains to be done on this topic from an academic point of view because it means decision makers should be able:

— to accurately measure net public investment and its long-term impact on growth and employment;

— to assess the "quality" of fundamental public goods and services and define minimum "quality" standards to be ensured;

- to identify public goods and services for which European added value is indisputable and which therefore deserve to be considered as European public goods and services and financed at the Community level

- to take a courageous decision to sanction a country that does not respect the rule. 


\subsection{Challenges and prospects for a common European public debt}

Some Member States of the EMU are more severely affected by the COVID-19 pandemic and faced with very difficult financial conditions that prevent them from implementing effective fiscal policies to fight the important adverse effects of the pandemic on the national economy. They are also menaced by a twin banking and sovereign debt crisis. The financial fragility of these Member States increases the risk of breaking up the euro area despite the aggressive monetary response of the ECB. To avoid these risks and accelerate economic recovery in Europe, it becomes urgent to pool some public debts at the level of the EU or the EMU with the aim of improving the public finances of highly indebted Member States or financing a European automatic fiscal stabilization mechanism.

\subsubsection{The need for a common debt instrument once again}

COVID-19 has triggered a shock of exceptional intensity that is causing one of the worst economic disasters in recent decades. This shock requires governments' interventions to provide financial support to mitigate the negative impact on household incomes and production by the firm, and further shield health systems and stimulate the economy when the COVID-19 pandemic recedes. National governments must intervene on a massive scale, meaning that government deficits will skyrocket and when the crisis is behind us, the governments will find themselves overloaded with an enormous public debt.

In this context, European countries experiencing the largest increase in budget deficits and public debt as a result of the coronavirus crisis (Italy, Spain, and France) are three of the four largest eurozone economies. Worse, all of this must be done at a time of declining tax revenues as long as economic activity remains repressed. Such an increase in public debt will call into question its sustainability in these countries, leading to the risk of a new sovereign debt crisis, as we saw in the eurozone during the $2010-12$ sovereign debt crisis.

Against this background, the present crisis management must make use of existing institutional mechanisms. Under certain circumstances, additional instruments could be introduced. Thus, no matter how governments challenge this mountain of debt (i.e. partial debt cancelation or "hair-cut", the ECB's Outright Monetary Transactions (OMT) program, assistance from the European Stability Mechanism (ESM), issuance of a common debt instrument: Eurobonds or 
corona bonds), this debt is likely to weigh on public policies for a long time. In any case, the fiscal potential of Eurobonds is more powerful than the hitherto untapped combination of assistance from the ESM in conjunction with the ECB's OMT program? Can Eurobonds or corona bonds solve the problem or do they merely treat the symptom?

It is crucial to find the optimal forms of joint action quickly and, of course, without modifying the European treaties. A low-cost and long-term funding instrument would be needed to avert a new debt crisis. In this case, more European solidarity will be needed, either by issuing "corona bonds", or by aid from the ESM, provided that the latter does not impose too severe reforms in return, with in addition, the ECB's sovereign bond buying program or OMT.

\subsubsection{Debating corona bonds: the proponents}

The mutual debt option or the principle of pooling national public debts (Eurobonds, or corona bonds) is a common debt instrument to jointly issue public debt across all Member States of the eurozone (see Blanchard et al. 2017; Benassy-Quéré et al. 2018). Among economists and politicians, regardless of their ideology, there is an ongoing heated debate between proponents and opponents of this ambitious possible budget option (Herzog 2020).

According to the proponents (see Varoudakis 2020), one advantage of this type of mutual debt would be the possibility of collecting long-term financing at low cost for the weak countries in the eurozone. The interest rate on common liability bonds would be low, possibly negative, as financial markets would not question the solvency of the eurozone as a whole, as opposed to the solvency of the high-debt countries or the vulnerable countries of the South.

As an additional advantage (see Dullien et al. 2010), the common liability bonds would offer a safe asset to eurozone banks, which are overexposed to their home countries' sovereign debt. As corona bonds would be at least as safe as German sovereign bonds and have a significant volume, they would provide a European safe asset to the financial system at a time of increased uncertainty, and could be used by the ECB for liquidity operations.

Moreover, by opting for a mutual debt, the Northern eurozone countries avoid the risk of "financial contagion" (see Varoudakis 2020). On the other hand, a new sovereign debt crisis in the Southern eurozone countries could potentially trigger such contagion by spreading to the banking systems of the North. Finally, the mutual debt option offers a joint line of defense against common 
risks for everyone, not only for the vulnerable countries of the South. It also offers the opportunity for the eurozone to improve its resilience in the future.

These are the principal reasons why a growing number of economists have called for the introduction of common instruments that provide fiscal support to Member States, enabling them to weather the crisis without dramatic increases in public debt. In this spirit, six prominent German economists (Bofinger et al. 2020) have recently proposed the issuance of a volume of $€ 1,000$ billion mutual bond (representing 8 percent of euro area GDP) to jointly raise funds to finance economic support packages during the pandemic.

\subsubsection{The opponents: inadequacy of corona bonds}

Despite the growing support for corona bonds by economists across the political spectrum, a number of economists have also called for the non-introduction of common instruments that don't provide fiscal support to Member States (see Herzog 2020).

A large body of academic literature suggests "moral hazard risks" in the eurozone. ${ }^{6} \mathrm{~A}$ huge collapse occurred as some Member States became more indebted and sought to externalize the cost of public debts to the others. This literature recommends precautions, implying either the adoption of strict fiscal rules as defined in the Maastricht Treaty, or a complete transfer of sovereignty, i.e. a political union (see Beetsma and Bovenberg 2000; Beetsma and Bovenberg 2003). Without a political union this mechanism is a profound illusion. On the other hand, with a political union in place, the instrument of joint public borrowing via Eurobonds would be fully endorsed. However, we can ask how realistic a political union is in Europe?

A second argument against the use of a common debt instrument is that the eurozone is not a state. ${ }^{7}$ There is no European fiscal sovereignty and hence no right to issue public debt. Moreover, there is no fiscal budget and no euro finance minister with cut-through clauses at the level of Member States. Fiscal policy as well as social, labor and health policies are the responsibility solely of Member States. These differences reflect country-specific political preferences (Herzog 2020).

Finally, despite the notion of being "united in diversity" centralized instruments will not solve the structural differences of eurozone Member States, as sovereignty and country-specific

\footnotetext{
${ }^{6}$ However, for a number of economists, corona bonds do not carry the risk of "moral hazard", which has often been spotlighted in the debate on Eurobonds, especially in Germany. After all, corona bonds are proposed as a one-off joint issuance for costs already incurred by an external event, the spread of the pandemic (Dullien et al. 2020).

${ }^{7}$ See the Treaty on the Functioning of the European Union (TFEU).
} 
preferences remain national. Fiscal sovereignty is particularly relevant to democracy, and it is assigned to the environment of the eternity clause of Article 79(3) of the Basic Law. In this respect, the President of the German Constitutional Court of Karlsruhe already signaled some time ago that the idea of Eurobonds touches on sensitive areas of the Basic Law. In other words, corona bonds may be difficult to implement in the eurozone due to both national and European legal constraints.

In the spirit of the previous reasons, the Netherlands has been the most vocal opponent of the idea of corona bonds, supported by Austria and Finland. However, it is safe to say that, ultimately, the opposition of the German government has been decisive in blocking the introduction of corona bonds. Thus, the Northern countries oppose the principle of pooling national public debts or mutual debt option.

Indeed, there is a gap between countries of the South, like Italy and Spain, among the most affected by the pandemic and with fragile finances, and those of the North, led by the Netherlands and by Germany and Austria, supporters of strict control over public finances.

The former, supported by France and seven other European countries (Greece, Portugal, Slovenia, Belgium, Luxembourg and Ireland, since joined by Cyprus) plead for the creation of a common instrument of debt pooling in the form of "corona bonds". The latter reject the idea of corona bonds, preferring the approach of the ESM, a rescue fund for the eurozone created in 2012. With a strike force of 410 billion euros in credit lines, the ESM is a conditional aid scheme, granted in return for drastic austerity plans on the part of beneficiary countries, as was the case in Greece, Portugal and Ireland.

\subsubsection{COVID-19 revives the gap between the north and the south?}

"The virus is back", said Jacques Delors on March 28, 2020. The former president of the European Commission deplores a "mortal danger" for the European project if by chance the member countries prove incapable of showing their solidarity. Disagreement in the eurozone has mostly revived the worry of the $2010-12$ sovereign debt crisis. At the time, there had already been talk of "euro bonds". Ten years later, the idea of corona bonds, opposed to that of the ESM, has generated the same violence and the same hostility on both sides.

Peter Bofinger, an economist and member of the German Committee of Sages, stressed (in an interview with the RedaktionsNetzwerk Deutschland 2020) the danger for the eurozone if it 
used the European Stability Mechanism (ESM) to deal with the economic consequences of the COVID-19 crisis, because it would not have a significant amount of funds for it to face a possible future euro crisis.

"The proposal to use the ESM to finance the corona crisis ignores the fact that it was created as security in the case of a crisis in the monetary union. If its funds are used to deal with the coronavirus crisis, we will find ourselves without protection in the next euro crisis". He warned that "Once the markets know this, the next euro crisis will come as soon as possible".

This eminent economist instead argued for so-called corona bonds "which are fundamentally different from the Eurobonds discussed in the euro crisis in 2011/12. At the time, it could be argued that Italy's problems were its own problem, and the help by using the Eurobonds send the wrong messages. However, for the coronavirus crisis, no one can blame Italy. In addition, unlike Eurobonds, the Member States of the eurozone could determine in advance exactly where the money would be given." Macroeconomic policies can therefore partially respond to the new challenges introduced by the COVID-19 crisis. In addition, structural policies also have a major role to play.

\section{Deepening structural policies to answer to the crisis}

Monetary and fiscal policies, mainly as countercyclical instruments even though they could also affect the structure of the economy, have an important role to play in tackling the effects of the COVID-19 crisis in the short run. But as mentioned earlier, their effectiveness may depend on structural characteristics of national labor markets. More generally, if the European economy is to become more resilient, structural policies need to be addressed. This section looks more specifically at three of them whose competences are shared: policies aimed at the labor market; those concerned with migratory flows; and policies of solidarity with the countries of the South through development cooperation policy. We then question the respective interests of the common policies and the policies pursued by the Member States.

\subsection{Are national labor market policies still relevant?}

Lockdowns, interruption of work to take care of children, restrictions on the mobility of people and goods: all these disrupted production systems and impacted the labor market. Whereas 
the US unemployment rate hit $14.7 \%$ in April (from a level of 3.5\% in February), the European unemployment increased only slightly between March and April (from 6.4\% to 6.6\%). But the situation is likely to get worse.

Faced with a large-scale supply and demand shock, companies had to reduce their production volume. This could be achieved either by reducing the number of employees (extensive margin adjustment) or reducing the number of hours worked (intensive margin adjustment) in a logic of hoarding the workforce. Countries usually differ in the use of these forms of adjustment. For example, during the 2009 crisis, the unemployment rate rose very sharply in Spain as a result of the heavy use of temporary contracts in that country, while it fell in Germany as German companies resorted to different schemes to preserve their workforce (Cochard, Cornilleau, Heyer 2010).

The effect of the shock also differs according to the type of workforce. The contraction in employment is generally observed with a lag in relation to the economic crisis. Companies facing difficulties start by not renewing temporary contracts and freezing their hiring plans. Young people most concerned by these types of contracts or in search of a job are the first to experience an increase in unemployment. If the difficulties persist or worsen, companies reduce the number of hours worked, downsize or even close down. Unemployment increases then further and affects a larger fraction of the population.

Yet, unemployment leaves its mark on people. It leads to a loss of income at the time and increases the likelihood of experiencing a further period of unemployment or lower wages (Arulampalam 2001; Gregg and Tominey 2005; Fares and Tiongson 2007; Cockx and Picchio 2012; Abraham et al. 2016; Ekert and Terraz 2011). When a previously jobless person returns to work, they may have a lower income than someone whose career has not been interrupted.

Economic theory offers a number of ways of explaining the wage penalty due to unemployment. In terms of human capital theory (Becker 1964), unemployment may be seen as the breakdown of an employment relationship for which the worker had developed skills and specific human capital. In this case, on taking another job, they will no longer be able to return to their earlier productivity and their earnings may be reduced. According to Spence (1973), the employer, with imperfect information, attempts to infer a person's productivity from information such as their educational qualifications. Extending this analysis, one may suppose that a period of unemployment may also be perceived as a negative signal of the unemployed person's abilities and 
lead the employer to reduce the wages offered (Oberholzer-Gee 2008; Kroft et al. 2013; Eriksson and Rooth 2014; Van Belle et al. 2018). The search and matching theory (Mortensen 1986) provides more nuanced conclusions whereby the impact of unemployment depends on the quality of the previous job match. A period of unemployment that destroys a "successful" match may lower the future earnings of the unemployed person if they find a job in which they are less efficient. Conversely, the break may be beneficial if it enables job seekers to find a better match and therefore be more productive. In particular, voluntary mobility may lead to better earnings. Some studies conclude that there is an unemployment penalty, more especially for young people. It appears that unemployment increases the probability of future unemployment (Fares and Tiongson 2007; Cockx and Picchio 2012; Nilsen and Reiso 2014; Schmillen and Umkehrer 2018) and lowers future wages (Gregg and Tominey 2005; Ghirelli 2015; Petreski et al. 2016; Scmieder et al. 2019).

\subsubsection{How to support workers and job seekers?}

What can governments do to prevent unemployment-related damages? A first course of action would be to preserve employment with the help of government subsidies. This is the main policy currently being implemented in Europe. At the end of April, 26.8\% of the workforce was covered by short-time work. Companies retain employees but reduce hours with the help of a government subsidy. Several positive effects are expected both for workers and firms. The system preserves human capital and avoids the stigma associated with unemployment. It also avoids firing and hiring costs for companies. One concern, however, would be that this would slow down the reallocation process of workers from low- to high- productivity firms. Examining the effect of short-time work during the financial crisis, recent literature concludes to a global positive effect of the measure (Cahuc and al. 2018 for France; Kopp and Siegenthaler 2019 for Switzerland; Giupponi and Landais 2018 for Italy). For instance, in France, the extension of short time work measures during the financial crisis has had a positive effect on employment and survival for firms which were affected by large negative revenue shocks and were highly indebted. The existence of a windfall effect was acknowledged but that did not counteract the positive one. Short-time work systems exist in a number of European countries but are mobilized differently. They are currently widely used in France, Italy and Luxembourg (Müller and Schulten 2020) and to a lesser extent (less than 5\%) in Poland, Bulgaria, Slovakia, Finland and Czechia.

If the unemployment rate is increasing, a second course of action is to compensate for income loss through the unemployment insurance system. An initial positive effect would be to 
cushion the effects of unemployment by supporting consumption and thus economic activity. A second one is related to the opportunity to seek work of good quality. Even if extensive literature documents the moral hazard effect of unemployment insurance (Lalive et al. 2006; Le Barbanchon 2016; Caliendo et al. 2013), these negative effects appear to be lower in the case of a recession (Kroft et al. 2013; Schmieder et al. 2012). Beyond these expected effects, State support for the European unemployed is heterogeneous in practice. Before the enlargement of 2004, EspingAndersen (1990) and Esping-Andersen et al. (2002) distinguished three models of social protection in Europe. The Nordic model with universal benefit coverage at high levels, a free-market model with less generous benefits, and a Continental model in the Bismarckian tradition of social insurance, whereby coverage is linked to employment and contributions based on salary. This typology reveals a first broad division regarding the generosity of social insurance, opposing the Nordic and free-market models, but does not describe the complete range of systems observed in EU countries. In particular, there are large differences in coverage rates and benefit generosity amongst countries where the Continental model applies. In Southern Europe, for example, many of the unemployed are not covered by social insurance.

Hence, short-time work and unemployment insurance systems appear to be crucial at times of economic crisis. They contribute to buffering the negative effects associated with unemployment but appear to be very heterogeneous across European countries. Faced with a major economic crisis, their cost is rising rapidly and is putting public finance under pressure.

\subsubsection{How to deal with the increasing "unemployment burden" at the European level?}

Labor market policies and social policies are the responsibility of the EU Member States. In the complex architecture of the distribution of competences within the EU, these policies are still decided at the national level. Some form of coordination exists but remains essentially nonbinding.

This choice can be discussed. At the beginning of European construction, the then sixmember states had different labor and social policies but they were all based on a Bismarckian system. The logic of the founding treaty of European construction was that the heterogeneity could be dealt with and that the social systems would converge under the pressure of trade unions and governments aiming at expanding social protection. The treaty of Rome stated that the intention 
was "to promote improved living and working conditions for the workforce, enabling them to have equal access to progress". But the enlargement of the European Union and the Single Market put national labor markets and social policies under pressure. The cost of labor is an issue in the context of the Single Market, all the more so since the enlargement to eastern European countries. The recent controversy on posted workers illustrates the complexity of the problem at the European level and the diversity of European social protection systems.

The COVID-19 crisis is putting national social protection systems back under great pressure. Should the response be dealt with at national or European level? On April 1st, the European response consisted in announcing the setting up of the SURE system. European governments can borrow from the EU to finance the consequences of unemployment. On 9 April, finance ministers approved the provision of $€ 100$ billion to help European countries. This is an undeniable step forward, but the payment is still made to the national unemployment insurance systems. The advantage is that the SURE system remains compatible with the diversity of national social protection systems. The crisis should be temporary and the system makes it possible to obtain financing to ensure the survival of businesses. One regret, however, is that harmonization between European social systems could have been more thorough. Faced with a common crisis, one could have imagined a common European response. There are several arguments in favor of such a response.

Mobility between European countries has increased sharply since the 2000s. Nearly 4 million people moved from the new Member States to the EU-15 between 2004 and 2014 (Flipo 2017). In the United Kingdom, for example, the increase in overall immigration is around 30 per cent between 2000 and 2010 and the number of Europeans there has increased sevenfold. But migration does not take place exclusively between the east and west of the European continent. After the public finance crisis, rising unemployment in the Mediterranean countries forced young people from Spain, Italy and Greece to search for jobs in other EU countries. Unemployment and low wages are at the root of intra-European migration movements. They are doing damage in the countries of origin, causing human capital losses and then jeopardizing their future development prospects. These movements can accentuate disparities within Europe. They also raise the question of the social security coverage of these persons.

Besides, the cost of labor is an important factor to be considered by firms that compete in a single market for goods and services. Social dumping can then be a way to gain market shares. 
In order to avoid competition between European countries on social aspects, it is necessary to minimize their differences. This is all the more urgent in a context of economic crisis and growing unemployment. The current crisis must not lead to increased competition between European countries. A European course of action would be, for instance, to set up a European minimum wage.

Over the last few decades, disparities in labor market rules and social systems have raised the question of a form of social dumping between Member States. The COVID-19 crisis may be a cause for concern as governments may be tempted to adopt non-cooperative behavior to solve their national problems. In the past, European integration has been able to move forward in times of crisis. It is time to design common social protection mechanisms so that the "harmonization in progress" pronounced by the Treaty of Rome becomes a reality.

\subsection{Frictions on the EU labor market}

The COVID-19 crisis may also reveal deeper structural imbalances in the labor market. Following OECD statistics, the working age population in OCDE area will grow between 2013 and 2020 by $2.2 \%$ while it will decline in the same proportion in the European Union. This decline could reach up to $3.5 \%$ under zero net migration scenario, especially in Germany, Italy and Poland. In addition, the labor market is undergoing deep structural changes with a considerable amount of net occupational change.

Apart from demographics, problems and the change in the skill composition of employment, the European countries and more particularly EU companies have difficulties finding workers with the right set of skills. The skills mismatch affects more than $40 \%$ of EU companies (the 2013 European Company Survey). Here again migration and immigrants have a role to play. In fact, migration can significantly contribute to extending the pool of skills available and should help to tackle skills mismatches considered as the main source of job dissatisfaction (Ayadi and Trabelsi 2017) and unemployment. Our core argument is that immigrants who have arrived more recently in Europe are more highly educated and qualified than immigrants who arrived years ago. Their new environment (host- countries) will help them capitalize, share, deploy their skills and contribute to ensure labor matching.

The European Agenda on Migration (May 2015) explicitly highlights the importance of attracting highly skilled foreign workers by reviewing the EU Blue Card scheme to make it more 
effective. The main objective of this European strategy is to improve job- and skill-matching through an efficient identification of skill gaps. Concretely, one million additional researchers would be needed to increase R\&D investment to $3 \%$ of GDP.

For countries severely affected by the COVID-19, it will not be an easy task to organize international labor migration to the EU. Therefore, the importance of a functioning, secure EU external border will be clearer, but also the need for a workable system of international labor migration into the single market.

In the following, we analyze the trend of occupation-shortage in European countries and identify the main key workers required to cope with the COVID-19 pandemic. We will then highlight the effects of the migration process, which is considered as the main policy instrument to address frictions in the European labor markets and to promote the region's global competitiveness.

\subsubsection{Shortage occupations and friction on the European labor market}

Understanding future skill needs, especially in the context of structural and situational transformation of the labor markets is essential to guide the integrated employment and migration policies. One can observe that ready-made human capital will no longer be available to employers in many EU Member States. This phenomenon is described as skill-shortages. Several reasons explain the emergence of this kind of labor market frictions; the more important are inevitably linked to the changes in the demographic composition of the labor force and in the skill composition of employment. The European countries and more particularly EU companies have difficulty finding workers with the right set of skills.

A European expert argued that Europe lacks 20 million skilled workers, it is important to identify the level of education required to fill the job vacancies, and the sectors which suffer from skill-shortages in order to make migration-inflow more efficient.

Following the statistics of Cedefop (2014), the projection of changes in employment between 2013 and 2050 indicates that Germany and Austria are more concerned by the changes in employment with $+2.6 \%$ followed by France and Benelux at $+1.0 \%$ relative to the baseline scenario. The United Kingdom and Ireland remain at the same level (due to Ireland's reduction) while Scandinavia decreases slightly. The imbalance increases at the highest level, usually followed by intermediate level qualifications. This pattern is found in Germany and Austria. France and Benelux have a different pattern given by a U-shaped development. 
These changes in employment will produce a general increase in the demand for skills over the medium to longer term, especially in the service sector. This increase will generate tensions between demand and supply trends and could create occupations shortage in several sectors. The software occupations, which were ranked as the most widespread shortage in the first three years of the study, drop to third, while Building Finishers and Related Trades Workers move from six to rank one between 2015 and 2016.

This projection aimed at ranking the occupation shortages are based on the changes in the demographic composition and other considerations like 2008 crisis. Following the ranking of shortage occupations, the health-care sector is only represented by Nursing and Midwifery Professionals classified as a low shortage occupation. However, the COVID-19 pandemic has raised the issue of the restructuring of this sector. In fact, over the next decade, it is anticipated that a considerable number of the new jobs created in the health sector will be in other occupational groups, like business, administration, ICT professionals and associate professionals. Thus, in the context of the health crisis and the new composition of the labor, markets characterized by the complementarity between the activities sectors (health care and ICT); Health is forecast to be a growth sector, with a net increase of 1.8 million jobs across the EU between 2013 and 2025. This will mainly be in occupations not related to medicine per se.

One can observe that health-sector employment is expected to grow at a rate of $0.3 \%$ per annum that is $8.1 \%$ between 2013 and 2025 much faster rate than overall EU employment $(+3.3 \%)$ from the same period. If we consider the need to replace employees leaving the sector for retirement, the health sector will experience a significant increase of 1.8 million jobs across the EU between 2013 and 2025. Following the European commission, the significant growth in the number of jobs in the health-care sector will require skills at both high and medium-level qualifications with 1.67 million and 753000 new job creations respectively. It is important to note that the forecast growth in medium-level jobs in health is more than twice the average rate $(7.8 \%$ in health compared to $3.4 \%$ for all sectors).

\subsubsection{Migration solution of the shortage occupations}

The participation rate could not unilaterally absorb the significant growth of new-creation jobs and it is more than likely that shortages will occur, especially among high-skilled professions. It is estimated (European commission) that there will be a shortfall of 1 million health workers by 
2020 across the EU. The most acute shortages in the supply of healthcare professionals will be in nursing, at 590,000 jobs, with physicians at 230,000 jobs and dentists, pharmacists and physiotherapists at 150,000 jobs.

Mobility within the EU could be the suitable policy to contain these imbalances by matching skills shortages and surplus for different activity-sectors. However, in the absence of solid law this strategy has not been fully successful, that is why the European members are supporting the development of comprehensive and evidence-based migration policies and legislation in line with European norms and standards. The proportion of immigrants among Key Workers confirms this strategic position. In fact, in most countries, the share of Extra-EU key workers is larger than the EU-mobile population. On average $13 \%$ of key workers are immigrants in the EU; this oscillates around $20 \%$ in countries such as Italy, Belgium, Germany, Sweden and Austria. The largest proportion is observed in Ireland Cyprus and Luxembourg with 26\%, 29\% and 53\% respectively. These shares vary from sector to sector within the European area and in many key occupations, like cleaners and helpers (more than 25\%), laborers in mining and construction-sector shares are substantially higher (about 14\%). Thus, migrant workers make important contributions to contain the skills shortages in both high- and low-skilled occupations. This finding was supported by the rapid spread of the COVID-19 contagion; in fact, some essential functions occupied by immigrants still need to be performed in order to keep European citizens healthy, safe and fed during this pandemic. Francesco Fasani (2020) argued that migrant workers are playing a major role in performing basic functions in European area affected by the COVID-19 epidemic. He added that migration constitutes, at least in the short term an important policy instrument to cope with the crisis and keep contributing to its solution. Italy took the decision to guarantee an amnesty for undocumented immigrants in order to address labor shortages in the agricultural and personal care sectors. The rest of European countries would shortly follow Italy's example and reactivate the migration process even though, in several countries such as Belgium, Netherlands, Luxembourg, public debates focus more on challenges relating to intra-EU mobility than on the labor migration of third-country nationals. A number of criticisms have been formulated as to the effectiveness of the EU legal framework for labor migration; in fact, according to the Commission's report (2015), the Blue Card Directive has made little impact on achieving its intended objectives. In 2012, only 3,664 Blue Cards were granted. This increased in 2013 to 15,261 (14,197, 306 and 304 for Germany, Luxembourg and France respectively). 
The big difficulties in managing global mobility and organizing international labor migration to the EU especially from countries severely affected by COVID-19, should make European governments wonder about the efficiency of labor migration in the short term. In consequence, it is important to focus on intra-EU mobility strategy and we need to keep the European labor market borders open even during the COVID-19 pandemic.

\subsection{Development cooperation policy in the face of the pandemic}

Beyond migratory flows, the European Union's relations with its partners in the South (countries in Africa, central and Latin America and in the Asia-Pacific area) are organized within the framework of development cooperation policy. This is a policy where competences are shared as far as the development aid component is concerned, but it also depends on the common trade policy as far as trade agreements, for example those with the ACP (African, Caribbean and Pacific) countries, are concerned.

The question of the European response to crises, particularly those affecting the African countries (for example, the 2015-migration crisis or the security crisis in the Sahel) where the most vulnerable are ${ }^{8}$, is often considered insufficient and poorly coordinated. The short-term European response to the COVID-19 crisis, and its feared and already foreseeable economic effects on the most vulnerable countries of the South, seeks to escape criticism.

The reasons for supporting the countries of the South, and especially Africa, in their fight against the effects of the pandemic are manifold and well known to the European institutions: a pandemic can only be fought effectively in a global manner without leaving any country behind; the increase in poverty that is likely to result can only increase migratory pressures, whether SouthSouth or North-South; even if China's weight in Africa increases, the EU remains Africa's leading trading partner and Africa an important supplier of raw materials to the EU.

This crisis comes at a time when the European development agenda is particularly busy: renewal of cooperation around the "European Consensus on Development" (European Commission 2017), the establishment of a new development financing instrument amounting to 89 billion euros, within the 2021-2027 multi-annual financial framework, which provides for integration of the EDF (European Development Fund) into the EU budget (European Commission 2018), and

\footnotetext{
${ }^{8}$ Between 2007-2008 and 2017-2018 Africa has been the first recipient of EU ODA (35\% to 45\% of the total).
} 
renegotiation of the Cotonou Agreement, on which the whole cooperation policy depends, including the EPAs (Economic Partnership Agreements) which are trade agreements currently being negotiated.

\subsubsection{The economic impact of COVID-19 on African countries}

The economic effects are already partly predictable and very significant due to the lack of safety nets and the impossibility of implementing policies similar to those of Northern countries to support their economies (Moore 2020; Steel and Phillips 2020) but also due to the heavy dependence on international markets.

Since the debt crisis, stabilization and structural adjustment policies, based on the comparative advantages that followed, have accentuated export specialization, generating a high dependence on unstable commodity markets and thus a significant vulnerability of the economies of the South (UNCTAD 2019; Guillaumont 2008). This vulnerability is all the greater since international taxes still account for a significant share of the budget revenues of the poorest countries. The unprecedented drop in prices (UNCTAD 2020, World Bank 2020) accentuates the already existing problems of oil countries (Nigeria, Chad, etc.) which do not have alternative resources.

Low-income countries are also affected by disruptions in the supply chains on which they depend for health products and especially for food for some of them. The effects of the health crisis

are in addition to those of a food crisis linked to a locust invasion in West and East Africa. In April, growth estimates ranged from -2.1 to $-5.1 \%$ and the most affected will be mining and oil-producing countries (Calderón et al. 2020).

This very particular crisis causes both a demand and a supply shock (Baldwin and Tomiura 2020; Sidiropoulos 2020) and the effects for African countries will depend on the extent of their exposure to international trade, tourism and foreign investment and the degree of lockdown (Wanjie and Ryder 2020).

In addition to export earnings, foreign investment and remittances from migrant workers are the most important sources of finance for the countries of the South. In Africa, FDI is mainly in the extractive sector, which has played a role in African growth over the past decade (Roe and Dodd 2017) and is affected, at least in the short term, by the decline in global demand (UNCTAD 2020). Remittances from migrant workers, whose amounts are sometimes as large as ODA 
(Official Development Assistance) funds, will decline as a result of the economic crisis that will follow the health crisis in the North. The World Bank predicts a historical decline of 23.1\% (Bisong et al. 2020).

This external vulnerability, rooted in the long term, reflects a path-dependence (Acemoglu and Robinson, 2012) which persists even though it could have been changed on various occasions thanks to a structural transformation (Aiginger and Rodrik 2020) announced in speeches (UNECA 2018) but which is still insufficient. In Europe as in Africa, everyone wants to see this crisis as an opportunity for a critical juncture leading to development paths that take better account of the long term and in particular sustainable development (Agenda 2030). In Africa, as in Europe, the worst is not certain, but we can also fear that "the world afterwards will be the same, only a little worse", with more inequalities, even more primary specialization in the event of the bankruptcy of local companies, etc. ${ }^{9}$

It is clear that coordinated European ODA will be more effective than dispersed interventions in limiting short-term risks, but both Africans and Europeans also want long-term structural changes, on which the common trade policy can have a large impact.

\subsubsection{EU development cooperation policy in response to the pandemic}

The EU's aid and cooperation policy has a financial dimension (ODA) and a trade dimension. "Aid and cooperation" policy is a shared competence between the EU institutions and the member countries; the common commercial policy, to which the EU-ACP Economic Partnership Agreements belong, is an exclusive competence of the EU except for those parts of the trade agreements that deal with arbitration tribunals and portfolio investment.

The EU is the largest donor of ODA, considering bilateral and joint aid, with two thirds of the amounts allocated by the OECD countries in the framework of a development aid policy in 2019, whose competences are shared between the European institutions and the Member States. Specific aid from the European institutions represents $10 \%$ of the total ODA of the OECD/DAC countries in 2019. Africa is the main recipient of ODA from the European institutions with $40 \%$ of the amounts granted in 2018.

\footnotetext{
9 "Rather than putting the world on a significantly different trajectory, it is likely to intensify and entrench alreadyexisting trends" (Rodrik, 2020).
} 
At the international level, Europe is initiating a moratorium on debt interest payments to free up resources to meet the additional costs associated with COVID-19. But cancelling the bilateral public debt of African countries, as requested by Senegalese President Macky Sall, is a false "good idea" inasmuch as it would above all facilitate the repayment of private creditors whose risk-taking is already remunerated by the high-interest rates at which they lend to African countries (Ferry, Sène and Raffinot 2020).

On 8 April 2020, the COVID-19 crisis was the subject of a response, in coordination with the United Nations, by the "Team Europe" composed of all the European institutions, member states and financial institutions (EIB, European Bank for Reconstruction and Development (EBRD, hereafter)) (European Commission 2020).

15.6 billion euros from existing European external action resources are being redirected to the fight against the COVID-19 in the partner countries. Complements from other sources (EBRD, Member States) will make it possible to reach a total of 20 billion euros to respond to the shortterm humanitarian emergency but also to finance research, health systems and the economic and social consequences of the pandemic (12 billion euros out of a total of 15) (European Commission 2020).

In the framework of the Paris (2005) and Busan (2011) agreements on the effectiveness of international aid, ODA coordination is one of the three principles guiding European ODA, along with complementarity (division of labor between Member States and the EU) and the coherence of other policies that can have an effect on development, in particular trade policy.

\subsubsection{Trade cooperation policy: a long-term perspective}

While respecting WTO rules (non-discrimination), the common trade policy offers the possibility to conclude asymmetrical bilateral agreements with developing countries or regions (WTO special and differential treatment). The trade dimension of European cooperation policy thus provides for the establishment of free-trade areas between the EU and some regions in the South, the so-called EPA (Economic Partnership Agreements) in the framework of the Cotonou Agreement. Although these asymmetrical FTAs eventually require less liberalization on the part of the countries of the South than the current situation, their establishment requires opening the 
borders of African countries to European manufactured products (Kern and Mainguy 2015) ${ }^{10}$. In the case of countries with such different economic structures, the advantages would lie in specialization according to comparative advantages (Venables 2003), which would imply a risk of increased primary specialization of African countries and, consequently, more economic vulnerability. However, these countries are already very much affected by the fall in prices linked to this crisis. Many countries of the South are dependent on imports of manufactured products, including for basic needs (Calderón et al. 2020).

The EPA are contested: studies show that they will have a greater impact on European exports than on those of African signatories (Fontagné, Laborde and Mitaritonna 2011); the gains linked to access to European markets would not really benefit LDCs and would be limited to a few agricultural products; they would create trade flow diversion effects (Viner 2014) with negative effects on regional integration between African countries, on the one hand, and significant reductions in budget revenues, on the other. This loss of revenue would reach $25 \%$ in the long term for ACP countries as a whole and 38\% for West African countries (Fontagné, Laborde and Mitaritonna 2011).

Studies considering the results of the latest negotiations show that the agreements will have overall weak, uneven and negative effects for LDCs. While consumer prices could fall in some cases, this gain would be offset by an increase in alternative taxes to those levied on imports of European products, thus providing an incentive for the necessary tax reform (Bouet 2018).

In the past, Europe's responses to international crises such as the September 11 attacks, the Arab Spring, the management of migration flows since 2015, and conflicts in the Sahel have had mixed results. Faced with the COVID-19 pandemic, the short-term response vis-à-vis partners, particularly in the South, is intended to be coordinated between all European aid stakeholders in the spirit of the Paris Agreement on Aid Effectiveness. At least initially, it seems that the European response vis-à-vis partners outside the Union is better coordinated than that concerning its own economy (Barbier-Gauchard 2020).

However, the effects of trade policies often involve much larger amounts than those of aid policies, and the EU's policy towards ACP countries is frequently contested. The various deadlines

\footnotetext{
10 The Cotonou Agreement is the successor to the Lomé Conventions which had been in force since 1975 and was based on non-reciprocal trade preferences. These trade agreements are called into question in the Cotonou Agreement because they did not comply with GATT principles (non-discrimination and reciprocity). The ACP countries therefore had to sign EPAs with the EU in order to maintain their preferential access to European markets, thereby committing themselves to gradually opening their markets to European products.
} 
for EU-Africa cooperation this year could be an opportunity to shift some of the cooperation policies, which are probably still too much in line with the Washington consensus, to others that are more conducive to 'structural transformation' (Aiginger and Rodrik 2020) that may reduce economic vulnerability.

\section{Renewed industrial policy and exchange rates}

In the two last sections, we have investigated several areas of economic policy which are complexly intertwined between the national level and the European level. Indeed, we have argued that the efficiency of the policy mix could be increased thanks to a better integration between monetary policy and fiscal policy. At the European level, we can recall that fiscal policy has been procyclical during the 2000s (Bénassy-Quéré et al. 2017). Besides, these cyclical policies can have an impact on the structure of the European economy as economic crises can have long-lasting effects (Fatás and Summers 2019). An artificial delineation between cyclical and structural policies must not be drawn. Thus, it seemed worthwhile to analyze whether an enhanced integration of some structural policies like labor market policy and cooperation policy could be mutually beneficial for the Member States. However, these aforementioned policies have a common feature, they share at least some competences with the European level. This is not the case for the industrial policy in which each country has followed its own national (non-)strategy. In the following, we discuss the renewed interest for a European industrial policy and its crucial implication for building a more resilient EU after the COVID-19.

\subsection{Industrial dynamics in the European Union before the pandemic}

Before the COVID-19 pandemic, as shown by Aiginger and Rodrik (2020), all European countries have experienced deindustrialization in terms of employment with the increasing competition due to the emergence of China. This phenomenon is especially acute in Italy and France, where the share of industrial activities in added value is below $10 \%$ in 2018 while this share was around 15\% in the mid-1990s. However, Germany, Austria and Ireland have managed to maintained their industrial shares thanks to a non-cooperative export-led growth strategy for Germany, to a new investment position after the EU enlargement for Austria and to tax competition for Ireland as we can observe in Table 1. 
Table 1. Shares of manufacturing in GDP

\begin{tabular}{|c|c|c|c|c|}
\hline & \multicolumn{2}{|c|}{ Nominal value added in manufacturing } & \multicolumn{2}{|c|}{ Real value added in manufacturing } \\
\hline & 1995 & 2018 & 1995 & 2018 \\
\hline Austria & 17.9 & 16.6 & 15.8 & 18.7 \\
\hline Finland & 22.2 & 15.3 & 13.9 & 15.8 \\
\hline France & 14.9 & 9.9 & 10.6 & 10.3 \\
\hline Germany & 20.6 & 20.8 & 19.3 & 21.5 \\
\hline Netherlands & 15.3 & 10.8 & 11.3 & 10.9 \\
\hline Sweden & 19.9 & 13.8 & 12.5 & 13.6 \\
\hline UK & 15.7 & 8.9 & 12.6 & 8.1 \\
\hline EU28 & 17.7 & 14.5 & 14.7 & 14.6 \\
\hline Euro Area & 18.0 & 15.4 & 15.2 & 15.7 \\
\hline CEEC & 19.7 & 18.9 & 14.1 & 19.5 \\
\hline Sub-Saharan Africa & 15.5 & 9.7 & 12.8 & 9.8 \\
\hline USA & 16.3 & 11.5 & 12.0 & 11.3 \\
\hline China & 32.6 & 29.4 & 23.4 & 26.2 \\
\hline World & 19.4 & 16.3 & 12.8 & 15.3 \\
\hline
\end{tabular}

Source: Aiginger and Rodrik (2020). Percentage shares in GDP.

Thus, the concerns about industrial policy in the European Union were at the heart of the economic policy discussions even before this crisis. Mazzucato et al. (2015) argue that the Great Recession has left permanent scars on European economies. Furthermore, they claim that some countries have been less affected than others as witnessed by the evolution of industrial shares in the added value. Besides, they question the current logic of the European institution in terms of Competition rules (that hinders de facto the emergence of European champions like the Airbus) in a world where China and, more recently the US, do not hesitate to provide large subsidies when strategic companies struggle to cope with international competition.

These last two points, heterogeneous consequences of the Great Recession on the industrial sectors and the lack of EU-wide industries, will be crucial to understanding the lack of coordination 
between EU Member States to face the Severe Acute Respiratory Syndrome coronavirus II outbreak. Indeed, the EU institutions were ill-prepared to face this peculiar crisis since their current institutional architecture is rigid and reacts to events instead of acting before events occur. These institutional weaknesses have been underlined by Ryan and Loughlin (2018) through a historical prism. These authors rightfully argue that the 'muddling through' approach adopted after the Euro crisis that occurred between 2010 and 2012 will be insufficient to face future crises. Indeed, the consequences of the Euro crisis are again heterogeneous in terms of unemployment, indebtedness and other macroeconomic indicators, still visible in several Member States.

\subsection{Industrial policies in the European Union}

As explained by Wigger (2019), the European Commission, in 2014, proposed to increase the manufacturing share of EU GDP from $15 \%$ to $20 \%$ by 2020 . As aforementioned, this target has not been reached since the long-term trends of deindustrialization have not been reversed for the EU as a whole, because of misconceptions and dogmas about industrial policy in the European institutions. The main objectives of this new European industrial strategy were to improve cost competitiveness (i.e. unit labor costs) as well as channeling private funds to industrial sectors thanks to the creation of multiple funds (a financial leverage effect was expected).

As the unit labor cost is the ratio between total labor compensation and productivity, a decrease in unit labor costs means that labor productivity grows faster than total labor compensation. Thus, the productivity gains which are not used to compensate the workforce could be used to finance future investment projects and to pay dividends to the shareholders. These reductions in unit labor costs could have a positive signaling effect in the private sector. As rightfully noted by Wigger (2019), productivity gains have slowed since the 1970s in the EU. This slowdown in productivity gains could be seen as a byproduct of deindustrialization. Consequently, and if we follow the rationale of the European institutions (European Commission 2014), improving cost competitiveness amounts to constraining the growth of wage costs. In the end, the

rationale behind these measures aimed at improving cost competitiveness is equivalent to internal devaluation.

One can wonder whether if the European institutions promotion of this strategy was really a good choice. This strategy was based on the income-switching expenditure effects expected from 
an internal devaluation (or an external devaluation which is impossible for euro area members). As noted by Doulos et al. (2020), the expected positive effects of internal devaluations can only occur when a country does not suffer from structural weaknesses (other than a non-flexible labor market). Indeed, countries like Greece could not retain international market shares, thus the benefits of internal devaluations have not been reaped but the drawbacks have been harshly experienced. In other countries which are more open to trade and less dependent on oil imports, internal devaluations have had some income-switching expenditure effects (Saadaoui 2018).

According to Pianta et al. (2020), the question in current policy debates is not whether we have to conduct an industrial policy in the European Union, but which industrial policy we need in order to ensure a good quality of life for European citizens. Firstly, we need to replace the old rationale based on cost competition by a new one in which unit labor costs will be improved thanks to new productivity gains (an increase in the denominator, not a decrease in the numerator as in internal devaluations). Secondly, we need to think of the European system of innovation as whole. Indeed, European projects like smart grids for photovoltaic parks in Europe could be an interesting example (see Zsyman et al. 2012).

Stimulating growth in innovative and sustainable sectors could increase labor unit costs, but this increase could still have a positive signaling effect for the private sector without inducing a large negative social cost in terms of unemployment, healthcare, living standards and, more generally in terms of well-being. These significant changes in industrial policy in Europe will not be achieved under current fiscal rules and competition rules as noted by Pianta et al. (2020).

\subsection{Industrial policy and exchange rates}

At the heart of the European Union, 19 countries out of 27 belong to the European Monetary Union. According to Eurostat, these countries represent more than $85 \%$ of the European Union GDP in 2019. Thus, currency developments in the EU must be analyzed through the lens of the euro. Besides, there is no exchange-rate policy for the euro, since its exchange rate arrangement can be classified as free floating (International Monetary Fund 2019).

This absence of exchange-rate policy along with a growing divergence in the euro area have severe consequences on industrial dynamics in the euro area, and more generally in the EU. Despite a nominal convergence in the run-up to the EMU, a real divergence has been observed between the 
Member States of the euro area since the middle of the 2000s as underlined by Eichengreen (2019). One can argue quite reasonably that these divergences in terms of real variables like GDP per capita or unemployment have structural determinants, but it also seems reasonable that the exchange rate and, by extension, the exchange rate policy has played a role in this real divergence. The euro exchange rate has played a role in European industrial dynamics.

In terms of international trade, it is not enough to think only about unit labor cost for a specific country. To fully grasp the potential impact of exchange rate policy on industrial policy, we need to introduce the notion of relative unit labor costs. Here, unit labor costs of different trade partners are compared to assess the external competitiveness of a country. For clarity purposes, we use the notations of Golub et al. (2018), the relative unit labor cost can be written as follows:

$$
R U L C=\frac{(L / Q)(W / L)}{\left(L^{f} / Q^{f}\right)\left(W^{f} / L^{f}\right) e}=\frac{(L / Q)}{\left(L^{f} / Q^{f}\right)} \frac{(W / L)}{\left(W^{f} / L^{f}\right) e}=\frac{q}{q^{f}} \frac{w}{w^{f} e}
$$

where $L$ stands for the labor employment, $Q$ is the added value, $W$ represents total labor compensation, the exchange rate $e$ is expressed in domestic currency per unit of foreign currency, and we add a superscript $(f)$ to the variables of foreign trade partners. It can be easily understood that a country with $R U L C$ lower than 1 will have a competitive advantage in manufacturing. As aforementioned, the dominant logic in European industrial policy before the COVD-19 crisis was to reduce $W$ as much as possible in order to attract private investors to industry.

Analyzing the role of cost-competitiveness in industrial dynamics provides only partial answers. There are other essential dimensions in industrial dynamics such as innovation dynamics, institutional dynamics and so forth. However, it seems to be interesting to explore whether exchange rate developments can have an impact on cost-competitiveness and consequently on the industrial dynamics. We introduce in equation (1), the equilibrium exchange rate, $e^{s}$ (i.e. an exchange rate consistent with macroeconomic fundamentals in the long-run) which now become:

$$
R U L C=\frac{q}{q^{f}} \frac{w}{w^{f} e^{s}} \frac{e^{s}}{e}
$$

From equation (2), we can see that a country's competitiveness will depend on three elements: (a) relative labor productivity, (b) relative nominal labor compensation times the inverse of the equilibrium exchange rate and (c) the exchange rate misalignment.

When the currency of the country depreciates (i.e. an increase in $e$ ), we can clearly see that the partial derivative of $R U L C$ with respect to $e$ is negative, besides a growing undervaluation of 
the currency (i.e. a depreciation above the equilibrium rate) will induce an advantage in terms of cost-competitiveness. For this country, this cost advantage will have positive consequences for manufacturing exports and consequently for added value and employment in the manufacturing sector. In fine, these exchange-rate misalignments will have an impact on economic growth and inflation as noted by Morvillier (2020).

During the 2000s, the exchange rate misalignments of each Member States become increasingly heterogeneous according to El-Shagi et al. (2016) and Villemot et al. (2018). Some peripheral countries like Greece, Portugal and Spain have experienced a growing undervaluation of their real effective exchange rates, whereas several core countries like Germany, the Netherlands and Austria have known a series of undervaluations for their real effective exchange rates. This growing heterogeneity will have important consequences on industrial dynamics in the euro area and in the EU. Economic growth and employment in the manufacturing sector for some Members states has been slowed because overvaluation means that the exchange rate $e$ is inferior to the equilibrium exchange rate $e^{s}$ in equation (2). Conversely, economic growth and employment in the manufacturing sector have been bolstered by cumulative undervaluations since the exchange rate $e$ is above the equilibrium exchange rate $e^{s}$ in equation (2). In this case, the $R U L C$ variable is inferior to 1 and the country has a competitive advantage against its trade partner as shown by Golub et al. (2018).

This problem was discussed and analyzed after the euro crisis which took place between 2010 and 2012. There is no doubt that stabilization measures will help to reduce the negative consequences of this growing heterogeneity between core and peripheral countries in the European Monetary Union. However, there is an underlying problem of cost-competitiveness and non-costcompetitiveness which can be only tackled by structural measures. These reforms should not be restricted to labor market reforms, but also applied to educational reforms, reforms of the banking system, reforms of the innovation system and renewed European industrial policy. It seems that these reforms have to be coordinated at the European level to face a violent exogenous shock like the COVID-19 pandemic. Pianta et al. (2020) argue convincingly that the current initiatives are on the right track.

The COVID-19 crisis has shown how a global exogenous shock could affect the functioning of the European institutions. In addition, coordination between Member States has been slow and to some extent inefficient. The most salient feature of the crisis in Europe has been the absence of 
coordination for the production of medical masks. We might consider it wise to build production capacities as part of plan for future pandemics (Feng et al. 2020). The lack of masks and tests along with a rapid implementation of measures of social distancing and hand washing in several European countries have been the most essential factors explaining the poor performance of European economies in the struggle against this novel coronavirus (Zhou et al. 2020; Shim et al. 2020; Cheng et al. 2020) in comparison with the performance of South-East Asian countries.

\section{Conclusion}

The current health crisis will morph into a severe economic crisis for the EU. According to the June update of the IMF's World economic outlook, the recession in 2020 will be above $10 \%$ in the euro area, and above 12\% for France, Italy and Spain. The IMF forecasts a slow economic recovery in 2022, but uncertainties remain high. In this general context, this paper has drawn up some perspectives to build a more resilient EU after the COVID-19. Furthermore, it is argued that the consequences of severe economic crises could have long-lasting effects and, therefore, an artificial delineation between short-term and long-run objectives should not be drawn.

Concerning stabilizing policies, the ECB takes an aggressive stance to deal with the great negative economic consequences of the COVID-19 pandemic. The scales of programs are very impressive even though they are dwarfed by those implemented by the FED. The ECB stands ready to add supplementary measures as soon as it finds that the existing programs and measures are not sufficient. However, the existing economic and institutional constraints make the efforts of the ECB more laborious and reduce its liberty to act. But on the other hand, these limits may make the ECB more credible and constitute a safety net preventing it from taking the path of high and uncontrollable inflation that would be detrimental to long-term economic growth and the stability of the euro area. It appears that a federal leap is desperately needed to increase the efficiency of the monetary policy by using common debt instruments to fight future catastrophic events, but this debt mutualization necessarily requires to design democratically 'smart' fiscal rules and to transfer some taxation powers to the EU level.

Besides, the coming economic depression will cause tremendous consequences in terms of unemployment and implies the need for changes in some structural policies. We argue again here that the federal level could be the appropriate level to answer to this challenge. Indeed, it is 
essential to be concerned about the long-term negative effects of unemployment. Doing so at the federal level would provide a common response to increased intra-zone mobility and the development of a form of social dumping. These negative evolutions could be heightened by demographic factors in Europe, thus, organizing international labor migration to the EU after the reopening of the borders could be a way to improve the efficiency of labor migrations. Moreover, as public finances will be under high pressure in the EU, the cooperation policy with African countries should be thought out and designed at the EU level to avoid contradictions between its different forms (official development assistance and trade agreements with the South), with the objective of enhancing its efficacy.

Lastly, to cope with future pandemics, which are far from being impossible, the EU and its Member States need to rebuild industrial capacities in several areas (textile products and medical equipment, etc.) which increase the resilience of the European economy. In this perspective, we can clearly see that the extreme fragmentation of global value chains has its advantages but has also enormous drawbacks when the world economy faces pandemics. The European Union and the Member States need to reorganize global value chains in order to increase the resilience of the European economies in a world where the outburst of other pandemics is far from impossible. The diversification of the supply source for medical equipment and pharmaceutical products should be a priority for European leaders. In this respect, this means that industrial capacities have to be renewed in Europe, but not necessarily in each European country alone if coordination between Member States is ensured even in crisis periods. 


\section{References}

1. Abraham, K. G., Haltiwanger, J., Sandusky, K., \& Spletzer, J. R. (2019). The consequences of long-term unemployment: Evidence from linked survey and administrative data. ILR Review, 72(2), 266-299.

2. Acemoglu, D., \& Robinson, J. A. (2012). Why nations fail: The origins of power, prosperity, and poverty. New York: Crown Business.

3. Aiginger, K., \& Rodrik, D. (2020). Rebirth of industrial policy and an agenda for the twenty-first century. Journal of Industry, Competition and Trade, 20(2), 189-207.

4. André, M. C., \& Dai, M. (2018). Learning, robust monetary policy and the merit of precaution. The B.E. Journal of Macroeconomics, 8(2), 1-20.

5. Arulampalam, W. (2001). Is unemployment really scarring? Effects of unemployment experiences on wages. The Economic Journal, 111(475), F585-F606.

6. Barbier-Gauchard, A., Baret, K. \& Debrun, X. (2021). Government efficiency and fiscal rules, in A. Afonso (Ed.), Handbook of Public Sector Efficiency. Cheltenham, UK: Edward Elgar Publishing.

7. Beck, H., \& Prinz, A. (2012). The Trilemma of a Monetary Union: Another Impossible Trinity. Intereconomics, 47(1), 39-43.

8. Becker, G. S. (1964). Human Capital: A Theoretical and Empirical Analysis with Special Reference to Education. Cambridge, MA: NBER.

9. Beetsma, R. \& A. Bovenberg (2000). Designing fiscal and monetary institutions for a monetary union. Pubic Choice, 102(3-4), 247-269.

10. Beetsma, R. \& A. Bovenberg (2003). Strategic debt accumulation in a heterogeneous monetary union. European Journal of Political Economy, 19(1), 1-15.

11. Bénassy-Quéré, A., Pisani-Ferry, J., Jacquet, P., \& Coeuré, B. (2017). Politique économique. Paris: De Boeck supérieur. 
12. Blanchard, O., Erceg, C. J. \& Lindé, J. (2017). Jump-starting the euro-area recovery: Would a rise in core fiscal spending help the periphery? NBER Macroeconomics Annual Conference, 31(1), 103-182.

13. Bouët, A., Laborde, D., \& Traoré, F. (2018). The European Union-West Africa Economic Partnership Agreement: Small impact and new questions. The Journal of International Trade \& Economic Development, 27(1), 25-53.

14. Brunnermeier, M. K., Garicano, L., Lane, P. R., Pagano, M., Reis, R., Santos, T., et al. (2016). Breaking the Sovereign-Bank Diabolic Loop: A Case for ESBies. American Economic Review, Papers and Proceedings 106(12), 508-512.

15. Calderón, C., Kambou, G., Djiofack, C. Z., Kubota, M., \& Korman, V. (2020). Africa's Pulse (No. 147542, pp. 1-136). The World Bank.

16. Caliendo, M., Tatsiramos, K., \& Uhlendorff, A. (2013). Benefit duration, unemployment duration and job match quality: a regression-discontinuity approach. Journal of applied econometrics, 28(4), 604-627.

17. Cheng, V. C., Wong, S. C., Chuang, V. W., So, S. Y., Chen, J. H., Sridhar, S., et al. (2020) The role of community-wide wearing of face mask for control of coronavirus disease 2019 (COVID-19) epidemic due to SARS-CoV-2. Journal of Infection, https://doi.org/10.1016/j.jinf.2020.04.024

18. Cochard, M., Cornilleau, G., \& Heyer, E. (2010). Les marchés du travail dans la crise. Économie et statistique, 438(1), 181-204.

19. Cockx, B., \& Picchio, M. (2012). Are short-lived jobs stepping stones to long-lasting jobs? Oxford Bulletin of Economics and Statistics, 74(5), 646-675.

20. Dai, M. (2011). Les 'hélicoptères' des banques centrales. Bulletin de l'OPEE, 24(1), 1723.

21. Dai, M., \& Spyromitros, E. (2012). A Note on Monetary Policy, Asset Prices, and Model Uncertainty. Macroeconomic Dynamics, 16(05), 777-790. 
22. Doulos, D., Katsaitis, O., \& Zombanakis, G. (2020). Is the emphasis on unit labor costs an effective export-promoting policy? A comparison between Greece and Portugal. Eurasian Economic Review, https://doi.org/10.1007/s40822-020-00145-2

23. Dullien, S., Theobald, T., Tober, S., \& Watt, A. (2020). Why Current EU Proposals for Corona-Related Financial Aid Cannot Replace Coronabonds. Intereconomics, 55(3), 152155.

24. Eichengreen, B. (2019). Convergence and Divergence in the EU: Lessons from Italy. Intereconomics, 54(1), 31-34.

25. El-Shagi, M., Lindner, A., \& Von Schweinitz, G. (2016). Real effective exchange rate misalignment in the euro area: A counterfactual analysis. Review of International Economics, 24(1), 37-66.

26. Eriksson, S., \& Rooth, D. O. (2014). Do employers use unemployment as a sorting criterion when hiring? Evidence from a field experiment. American economic review, 104(3), 1014-39.

27. European Commission (2014). For a European Industrial Renaissance. https://ec.europa.eu/growth/industry/policy/renaissance_en

28. European Commission (2017). European consensus on development, International Cooperation and Development. https://ec.europa.eu/international-partnerships/europeanconsensus-development_en

29. European Commission (2018). EU budget for the future. https://ec.europa.eu/commission/news/eu-budget-future-2018-dec-04_en

30. European Commission (2020). Joint communication to the European Parliament, the council, the European economic and social committee and the committee of regions. https://ec.europa.eu/info/live-work-travel-eu/health/coronavirus-response/crisismanagement-and-solidarity_en

31. Esping-Andersen, G. (1990). The three worlds of welfare capitalism. Princeton, NJ: Princeton University Press. 
32. Esping-Andersen, G., Gallie, D., Hemerijck, A., \& Myles, J. (2002). Why we need a new welfare state. New York: OUP Oxford.

33. Fatás, A., \& Summers, L. H. (2018). The permanent effects of fiscal consolidations. Journal of International Economics, 112, 238-250.

34. Flipo, A. (2017). Les migrations de travail intra-européennes entre ruptures et continuités. Hommes \& migrations, (1317-1318), 69-77.

35. Fontagné, L., Laborde, D., \& Mitaritonna, C. (2011). An impact study of the economic partnership agreements in the six ACP regions. Journal of African Economies, 20(2), 179216.

36. Ghirelli, C. (2015). Scars of early non-employment for low educated youth: evidence and policy lessons from Belgium. IZA Journal of European Labor Studies, 4(1), 20.

37. Giannoni, M.P. (2002). Does model uncertainty justify caution? Robust optimal monetary policy in a forward-looking model. Macroeconomic Dynamics, 6(1), 111-144.

38. Giordani, P., \& Söderlind, P. (2004). Solution of macromodels with Hansen-Sargent robust policies: Some extensions. Journal of Economic Dynamics and Control, 28(12), 2367-2397.

39. Golub, S. S., Ceglowski, J., Mbaye, A. A., \& Prasad, V. (2018). Can Africa compete with China in manufacturing? The role of relative unit labour costs. The World Economy, 41(6), 1508-1528.

40. Gonzalez, F., \& Rodriguez, A. (2013). Monetary Policy Under Time-Varying Uncertainty Aversion. Computational Economics, 41(1), 125-150.

41. Gregg, P., \& Tominey, E. (2005). The wage scar from male youth unemployment. Labour Economics, 12(4), 487-509.

42. Guillaumont, P. (2009). An economic vulnerability index: its design and use for international development policy. Oxford Development Studies, 37(3), 193-228.

43. Hansen, L.P., \& Sargent, T.J. (2007). Robustness. Princeton, NJ: Princeton University Press. 
44. Herzog, B. (2020). Whither Coronabonds? The Past and Future of the EMU in the Coronavirus Pandemic. Intereconomics, 55(3), 155-158.

45. Horton, R. (2020). The COVID-19 Catastrophe: What's Gone Wrong and How to Stop It Happening Again. Cambridge: John Wiley \& Sons.

46. Kern, F., \& Mainguy, C. (2015). La politique de développement de l'Union entre logique commerciale et solidaire. In Dévoluy, M. \& Koenig, G. (Ed.), Les Politiques économiques européennes. Paris : Editions Points.

47. Kroft, K., Lange, F., \& Notowidigdo, M. J. (2013). Duration dependence and labor market conditions: Evidence from a field experiment. The Quarterly Journal of Economics, 128(3), 1123-1167.

48. Kroft, K., Lange, F., Notowidigdo, M. J., \& Katz, L. F. (2016). Long-term unemployment and the Great Recession: the role of composition, duration dependence, and nonparticipation. Journal of Labor Economics, 34(S1), S7-S54.

49. Lalive, R., Van Ours, J., \& Zweimüller, J. (2006). How changes in financial incentives affect the duration of unemployment. The Review of Economic Studies, 73(4), 1009-1038.

50. Leitemo, K., \& Söderström, U. (2008b). Robust monetary policy in a small open economy. Journal of Economic Dynamics and Control, 32(10), 3218-3252.

51. Le Barbanchon, T. (2016). The effect of the potential duration of unemployment benefits on unemployment exits to work and match quality in France. Labour Economics, 42, 1629.

52. Markel, H., Lipman, H. B., Navarro, J. A., Sloan, A., Michalsen, J. R., Stern, A. M., et al. (2007). Nonpharmaceutical interventions implemented by US cities during the 1918-1919 influenza pandemic. Journal of the American Medical Association, 298(6), 644-654. https://jamanetwork.com/journals/jama/article-abstract/208354

53. Mazzucato, M., Cimoli, M., Dosi, G., Stiglitz, J. E., Landesmann, M. A., Pianta, M., et al. (2015). Which industrial policy does Europe need? Intereconomics, 50(3), 120-155.

54. Mortensen, D. T. (1986). Job search and labor market analysis. Handbook of Labor Economics, 2, 849-919. https://doi.org/10.1016/S1573-4463(86)02005-9 
55. Morvillier, F. (2020). Do currency undervaluations affect the impact of inflation on growth? Economic Modelling, 84, 275-292.

56. Musgrave, R. A. (1959). The theory of public finance. New-York: Mac Graw-Hill Book Company.

57. Nilsen, Ø. A., \& Reiso, K. H. (2014). Scarring effects of early-career unemployment. Nordic Economic Policy Review, 1, 13-46.

58. Oberholzer-Gee, F. (2008). Nonemployment stigma as rational herding: A field experiment. Journal of Economic Behavior \& Organization, 65(1), 30-40.

59. Onatski, A., \& Stock, J.H. (2002). Robust monetary policy under model uncertainty in a small model of the U.S. economy. Macroeconomic Dynamics, 6(1), 85-110.

60. Petreski, M., Mojsoska-Blazevski, N., \& Bergolo, M. (2016). Labor-market scars when youth unemployment is extremely high: evidence from Macedonia. Eastern European Economics, 55(2), 168-196.

61. Pianta, M., Lucchese, M., \& Nascia, L. (2020). The policy space for a novel industrial policy in Europe. Industrial and Corporate Change, 29(3), 779-795.

62. Qin, L., Sidiropoulos, M. \& Spyromitros, E. (2013). Robust monetary policy under model uncertainty and inflation persistence. Economic Modelling, 30(C), 721-728.

63. Ryan, J., \& Loughlin, J. (2018). Lessons from historical monetary unions-is the European monetary union making the same mistakes? International Economics and Economic Policy, 15(4), 709-725.

64. Saadaoui, J. (2018). Internal Devaluations and Equilibrium Exchange Rates: new evidences and perspectives for the EMU. Applied Economics, 50(59), 6364-6381.

65. Schmieder, J. F., Von Wachter, T., \& Bender, S. (2012). The effects of extended unemployment insurance over the business cycle: Evidence from regression discontinuity estimates over 20 years. The Quarterly Journal of Economics, 127(2), 701-752.

66. Schmillen, A., \& Umkehrer, M. (2018). The scars of youth: Effects of early-career unemployment on future unemployment experience. International Labour Review, 156(34), 465-494. 
67. Shim, E., Tariq, A., Choi, W., Lee, Y. \& Chowell, G. (2020) Transmission potential and severity of COVID-19 in South Korea. International Journal of Infectious Diseases, https://doi.org/10.1016/j.ijid.2020.03.031

68. Spence, M. (1973). Job Market Signaling. The Quarterly Journal of Economics, 87(3), 355-374.

69. UNCTAD (2019). Handbook of statistics. https://stats.unctad.org/handbook/MerchandiseTrade/ByProduct.html\#map1_figure

70. UNCTAD (2020). The Covid-19 Shock to Developing Countries: Towards a "whatever it takes" program for the two-thirds of the world's population being left behind. Trade and Development Report Update, https://unctad.org/en/PublicationsLibrary/gds_tdr2019_covid2_en.pdf

71. UNECA (United Nations. Economic Commission for Africa) (2018). Natural Resources Governance and Domestic Revenue Mobilization for Structural Transformation. African Governance Report V, https://www.uneca.org/sites/default/files/PublicationFiles/agrv_en.pdf

72. Van Belle, E., Di Stasio, V., Caers, R., De Couck, M., \& Baert, S. (2018). Why are employers put off by long spells of unemployment? European Sociological Review, 34(6), 694-710.

73. Venables, A. J. (2003). Winners and losers from regional integration agreements. The Economic Journal, 113(490), 747-761.

74. Villemot, S., Ducoudré, B. \& Timbeau, X. (2018). Taux de change d'équilibre et ampleur des désajustements internes à la zone euro. Revue de l'OFCE, 155(1), 303-334.

75. Viner, J. (2014). The customs union issue. New York: Oxford University Press.

76. Wigger, A. (2019). The new EU industrial policy: authoritarian neoliberal structural adjustment and the case for alternatives. Globalizations, 16(3), 353-369.

77. World Bank (2020) World Development Report 2020 : Trading for Development in the Age of Global Value Chains. Washington, DC: World Bank. 
78. Zhou, Z., Yue, D., Mu, C. \& Zhang, L. (2020) Mask is the possible key for self-isolation in COVID-19 pandemic. Journal of Medical Virology, https://doi.org/doi:10.1002/jmv.25846

79. Zsyman, J., Huberty, M., Behrens, A., Colijn, B., Tol, R. S., Ferrer, J. N., et al. (2012). Green growth. Intereconomics, 47(3), 140-164. 